Discussion

Papers

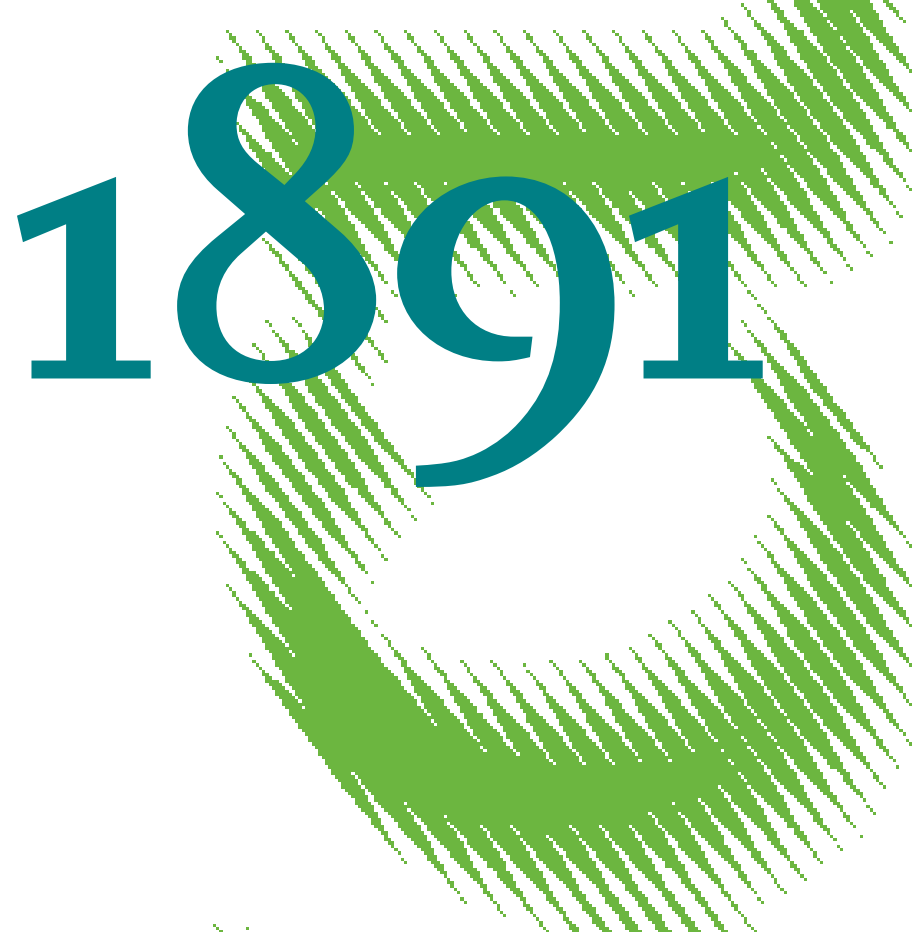

Inform Me When It Matters:

Cost Salience, Energy Consumption, and Efficiency Investments 
Opinions expressed in this paper are those of the author(s) and do not necessarily reflect views of the institute.

IMPRESSUM

(C) DIW Berlin, 2020

DIW Berlin

German Institute for Economic Research

Mohrenstr. 58

10117 Berlin

Tel. +49 (30) $89789-0$

Fax +49 (30) $89789-200$

http://www.diw.de

ISSN electronic edition 1619-4535

Papers can be downloaded free of charge from the DIW Berlin website:

http://www.diw.de/discussionpapers

Discussion Papers of DIW Berlin are indexed in RePEc and SSRN:

http://ideas.repec.org/s/diw/diwwpp.html

http://www.ssrn.com/link/DIW-Berlin-German-Inst-Econ-Res.html 


\title{
Inform Me When It Matters: Cost Salience, Energy Consumption, and Efficiency Investments
}

\author{
Puja Singhal*
}

July 8, 2020

\begin{abstract}
Effective attention to information may play a prominent role in consumer choice for energy-intensive services and it may simply be a function of receiving timely information when consumption takes place. This paper investigates whether and why the timing of utility bills leads to salience bias in heat energy consumption. In Germany, the 12-month billing period varies across buildings with a significant share of buildings receiving bills during the summer months, when the salience of heating costs is absent or low. I exploit this large-scale natural experiment in utility billing cycles at the building level to identify the salience effect of costs on energy consumption and the underlying heterogeneity in the average treatment effect. I find new evidence for consumer inattention to energy costs: consumers that are billed for heating during off-winter months demand more heat energy annually. Results suggest that households are paying attention to their heating costs in the first three months of the 12-month billing period. As a result, bills immediately before the winter heating season are most effective, allowing ample opportunity to adjust consumption. I show that salience bias in consumption is persistent and pervasive - affecting households in all regions and building/technology type. Engaging energy users with salient bills, not necessarily more frequent, has the potential to reduce energy consumption in the residential sector significantly. This paper further examines whether enduring differences in consumer inattention to energy costs had a long-run impact on thermal efficiency investments by building owners - with implications for the energy-efficiency gap.
\end{abstract}

Keywords: Heating Bills, Natural Experiment, Cost Salience, Consumer Inattention, Energy Consumption, Energy Efficiency

JEL Codes: D12, Q41, Q58, Q52

\footnotetext{
*Berlin School of Economics (Free University of Berlin \& DIW Berlin), email: psinghal@diw.de. I am grateful to Peter Haan, Carsten Schröder, Ximeng Fang, and Georg Weizsäcker for feedback. I would like to thank the SOEP Applied Panel group, the Berlin Behavioral Economics group, and participants at the Virtual EAERE conference, 13th RGS Doctoral Conference (Dortmund), BSE Micro workshop at the Hertie School of Governance, and the Sustainability Brown Bag Seminar at DIW Berlin for helpful comments. I thank ista Deutschland GmbH (ISTA) for answering questions regarding their data and billing cycles. Any errors are my own. Disclaimer: ISTA was not involved in the analysis, writing, or review of this paper in anyway. The author has no financial interests to disclose.
} 


\section{Introduction}

Behavioural economic theory challenges standard assumptions that agents are fully attentive to information when making economic decisions (DellaVigna, 2009). For boundedly rational agents, the value of information may depend on when it is delivered to the decision maker. This is because the agent receiving the information has limited and varying degrees of attention $-\mathrm{a}$ scarce resource.

A number of studies confirm the theoretical prediction of consumer inattention - consumers react less to information that is relatively less salient. Effective attention to information may simply be a function of receiving timely information when making the consumption choices. Chetty et al. (2009) show using a field experiment that tax-inclusive prices at the grocery store induced a stronger behavioral response than sales tax added at the register. DellaVigna and Pollet (2009) find that investor response to information on stock earnings is stronger when the announcements are received during the weekday, when attention is more likely. Empirical work demonstrates that automated payment technology reduces price salience when agents do not need to view costs or prices, whether it is during payment of road tolls (Finkelstein, 2009) or monthly electricity bills (Sexton, 2015). Consumers become less price elastic or do not perceive the full cost of consumption, leading to an increase in consumption.

In the field of environmental economics, providing consumers real-time information on usage and prices has been shown to significantly reduce electricity and water demand (Jessoe and Rapson 2014, Pon 2017, Tiefenbeck et al. 2018). But does more frequent information have long-lasting effects and when or for whom is it more effective? Prest (2020) demonstrates using machine learning methods that consumer awareness is most predictive of heterogeneous demand response to time-of-use prices displayed on in-home monitors. In the intermittent billing context, Wichman (2017) evaluates the response of water use in response to an increase in the frequency of billing information (bi-monthly to monthly) and finds that the intervention was ineffectual for inattentive consumers. In contrast, more frequent billing improved the transparency of costs and increased consumption for large water users during the summer. Even with routine monthly billing for electricity consumption, Gilbert and Zivin (2014) show that households alter consumption behaviour significantly only in the first week after the bill arrives and that this response is stronger during the hotter months, when consumption is likely higher. These studies demonstrate that the effectiveness of information treatments is largely driven by high baseline users, during peak consumption periods, when usage costs are most salient.

Given that salience of information plays a prominent role in consumer attention to energy costs, I consider in this paper whether the timing of bills is a factor in determining heat energy demand by households. More specifically, I investigate the effect of (not) receiving billing information when it matters the most for heat energy demand - during the heating season. The delivery of heating bills in Germany is relatively unique compared to that in other countries. Households receive energy bills once a year, as opposed to quarterly or monthly, with information on annual usage, prices, and charges ${ }^{1}$. Moreover, the 12 -month billing period varies from building to building - that is, the closing date for billing (meter reading date) is not always the end of December ${ }^{2}$.

\footnotetext{
${ }^{1}$ The consumer makes monthly advance payments (in equal installments, called "Abschlag") towards the annual bill. At the end of the billing period, each consumer then receives an individualized-consumption bill (since 1981 due to the Heat Cost Ordinance), a summary invoice with the actual consumption and costs, along with the final sum to be refunded or due as payment after factoring in the advance payments.

${ }^{2}$ The beginning or the end of the billing period largely depends on the type of energy with which the billable
} 
To my knowledge, this paper is the first in the literature to exploit the unique natural experiment in billing cycles to understand whether heat demand reacts to salience of information (consumption, costs of energy, and payment settlement) on energy bills. For households receiving heating bills during the summer or low usage months, misperceptions of the true cost of heating energy are likely to be higher when winter comes along and these misperceptions are increasing with consumer inattention to untimely bills. In other words, salience of heating energy costs is arguably elevated during the winter months, when most of the heating consumption takes place ${ }^{3}$. In this setting, inattention arises simply because of the temporal distance between when heating costs are revealed and when heating is used. Moreover, this temporal distance is exogenous to the decision of households residing in a building - in terms of potential energy consumption outcomes.

I find new evidence for consumer inattention to energy bills and show that heat energy demand is sensitive to time-varying salience of heating costs. Compared to buildings with calendar year billing, I find that off-winter billing accounts cause residential buildings to consume on average up to 9 percent more heat energy every year from 2008 to 2018, a period of both increasing and decreasing, but relatively high fuel prices ${ }^{4}$. I provide evidence that over-consumption due to lack of salience of heating costs and bills is pervasive and applies to all building types and fuel sources. Moreover, these ATE estimates capture the long-term effects - lingering behavioral bias after learning and compensating adjustments have taken place on the part of consumers over time $^{5}$. Most importantly, I show that salience bias is sensitive to the 3-month sum of heating degree days post-billing, suggesting that households are effectively adjusting consumption in the first three months of the year-long billing cycle.

Unlike space heating, energy for water heating is consumed year-round and thus should not be as sensitive to billing cycle treatments. I test the same mechanism on hot water use and find consistent results, offering an interesting insight. Households billed during the off-heating season cut back on water heating use to compensate for the lack of salience and inability to adjust annual energy consumed for space heating. This provides evidence that the results are driven by time-varying salience and consumer inattention to heating costs.

This study also contributes to the understanding of any distributional concerns due to consumer inattention to energy bills. I take advantage of regional inequality to explore heterogeneous impacts. It is perhaps ambiguous how the rate of overconsumption should vary with the socioeconomic status of households living in a given building ${ }^{6}$. I estimate average treatment effects

building is heated. The distinction comes from whether the heating fuel is supplied directly by a utility company or bought by the owner of the building. Thus, the billing cycle of the building is determined by the purchase cycle of the owner (for oil, wood, pellets) or the supply cycle of the supplier (for natural gas or district heating). For a significant share of buildings the heating bills end during the summer months April to August.

${ }^{3}$ The majority of the heating costs incurred by households in Germany are due to space heating, for which the demand is practically zero during the summer season. See Table 1 for information on the average temperature and heating degree days experienced each month of the year from 2003 to 2018.

${ }^{4}$ We expect households that are unable to react timely (during winter season) to billing information to be less affected in response to price declines. But heating fuel prices were relatively high for most of the sample time period. See Appendix: Figure A1.

${ }^{5}$ This is because the buildings in my sample do not change billing cycles, unless undergoing refurbishments or change heating fuel. This is apparent in the data as the buildings (about $5 \%$ of total) drop out from the panel, before I observe a change in the billing cycle. Results are robust to limiting the sample to buildings that do not switch billing cycles from 2008 to 2018 .

${ }^{6}$ I expect tighter budgets should cause households to be, cetris paribus, more attentive to energy costs and demonstrate better learning of price expectations and billing information - leading to lower estimates of overconsumption. 
by terciles of the unemployment rate distribution and find that the timing of bills is just as important, if not more, for energy consumption by households living in poorer socioeconomic zip codes.

Using complementary data on energy performance certificates for a subset of buildings, I further investigate the potential long-term impact of salience bias (higher heating expenditures) on thermal-efficiency investments by building owners. To this end, I find novel evidence that nonsalience of costs not only affected short-run yearly consumption outcomes by residents, but also fed into long-run investment decisions by the landlord or owner of the building. Specifically, I argue that higher heating expenditures over time provided stronger financial incentives for buildings most prone to salience bias in consumption to renovate and improve the thermal-insulation features of buildings. This further implies that building owners were indeed paying attention to annual energy costs and potential returns to energy efficiency investments. These differences in efficiency investments across billing cycles highlight that, at least for multi-apartment buildings, owners of buildings did invest towards closing any perceived energy-efficiency gaps, which were driven by consumer misoptimization by tenants, treated with low salience of energy bills.

The rest of the paper explains the findings in much more detail. The next section briefly presents a simple model of cost-salience that would apply to the empirical setting. Section 3 describes the data used in this paper. Section 4 assesses whether the stratified treatment assignment is as good as random and informs the research design. Section 5 presents the main empirical methodology and results, while Section 6 considers heterogeneity in the ATE with respect to the unemployment rate. Section 7 presents a battery of additional tests to check the robustness of the identification strategy and results. Section 8 investigates whether salience bias in consumption had long-term effects on energy-efficiency investments by building owners. In Section 9 , I adapt the empirical strategy to account for potential selection bias concerns when considering all fuel sources and building types. Sections 10 and 11 conclude.

\section{Theory}

Here I use the model described in Sexton (2015) to capture diminished salience of energy costs related to billing that takes place during the off-heating season.

Suppose individuals enjoy an energy-related activity $M$ at home, which is produced using an energy good $X$ and technology $\alpha$, according to $m=\alpha x$. Let $p$ be the exogenous price of good. Suppose further that individuals derive utility from consuming a numeraire good, L. An individual's utility function is quasi-linear $U(l, m)=l+\theta V(m)$ and $\theta$ represents a taste parameter and function $V$ is a twice differentiable and strictly concave function.

Consumer inattention related to diminished salience features in the model by assuming that individuals receiving bills during the summer potentially misperceive costs and observe only $\delta \in(0,1]$ of the true price of energy $X$ - that is, $\tilde{p}=\delta p$, where $\delta=1$ indicates full attention.

We could also consider the receipt of a bill ("Abrechnung") as a "true cost shock" that makes the consumer more attentive and that the "true cost shock" is more salient during the winter when consumption takes place.

The perceived optimization problem is then

$$
\max _{x} U(l, m)=l+\theta V(\alpha x)
$$


subject to

$$
I=l+\delta p x
$$

Assuming an interior solution we have that

$$
V^{\prime}(m)=\frac{\delta p}{\theta \alpha}>0
$$

The straightforward prediction, therefore, is that keeping technology, tastes, and prices constant, greater inattention or reduced salience of the true cost of energy causes above-optimal consumption levels.

\section{Data}

The primary data used in the analysis are a large panel of building-level heating bills for over 300,000 residential buildings in Germany from January 2008 to June $2018^{7}$. The sample covers residential apartment buildings using all main fuel types, with 2 or more apartment units, with very good regional coverage - over 7000 postal codes in all sixteen states of Germany are represented. I observe a building on average 9 times and a maximum number of 11 times.

The billing dataset provides information on the actual units of energy consumed for space heating and water heating, along with yearly prices and expenditures incurred. The billing data also contains important building characteristics that help determine the energy requirements of buildings: living space (in square meters), building size (in number of apartments), location, and heating fuel type. To complement this information, I further observe information provided on energy performance certificates (EPC) issued from 2008 to 2018 (for about 40\% of the buildings), on energy performance scores, year of construction, and the year of construction or renovation of key building components such as the heating system, roof, top floor or loft ceiling, outer wall, windows, and basement ceiling. For an even smaller subgroup of buildings (about 15\%), I further observe whether these key building components met thermal-efficiency standards regulated under the 1995 Thermal Insulation Ordinance (Wärmeschutzverordnung or WSVO 1995) at the time of certification.

The main dependent variable is calculated as the annual quantity of heating energy consumed in relation to the heated living space of a building. This took several steps: first, building-specific consumption values are limited to the amounts of energy used for heating space (excluding warm water). Second, the consumption value is multiplied by the heating value corresponding to the building's energy fuel type, giving us the absolute heating energy consumption in kilowatt-hours (kWh) for a building during the billing period. Lastly, I divide total kilowatt-hours consumed by the amount of heated living space in the building. The units for heat energy consumption are therefore, kilowatt-hours per square meter of heated living space per year $(\mathrm{kWh} / \mathrm{sqm})$.

I calculate heating costs used for the heating energy consumed by first deducting costs of heating water from the total energy costs reported in each bill. Then dividing total costs for space heating by the total $\mathrm{kWh}$ units of heat energy consumed in the building gives us the cost per $\mathrm{kWh}$ of heat energy billed.

I supplement the billing dataset with weather station data from the German meteorological service (Deutscher Wetterdienst). I find the nearest available weather station to 8303 geocoded

\footnotetext{
${ }^{7}$ The data is confidential and was received as part of a partnership between DIW Berlin and ista Deutschland GmbH to produce the Heat Monitor (Singhal and Stede, 2019) at DIW Berlin.
} 
zip codes of Germany, provided that there is not more than one consecutive daily observation record missing for mean temperature for each weather station from 2003 to 2019. For the few missing values, I impute using the average of mean temperatures recorded for the previous and next day. This procedure amounts to using daily mean temperatures from 204 weather stations scattered across Germany to calculate heating degree days corresponding to each billing month and cycle.

The socio-economic variables used in this paper are the unemployment rate and the purchasing power ${ }^{8}$ per household computed using grid level (1x1 kilometer cells) data from RWI and microm (2020), aggregated to the zip code level and matched to the billing sample. Currently, this information is only available for 2005 and 2009 to 2017.

\section{Billing Cycles - A Natural Experiment?}

In this section, I explore whether the billing cycle assigned to a building is independent of residing households' consumption behaviour.

In general, the beginning or the end of the billing period depends on the type of energy with which the billable building is heated ${ }^{9}$. The distinction is due to the supply of heating fuel. Natural gas and district heating are supplied to the building directly through an energy supplier and thus the billing cycle is determined by the billing cycle of the supplier. On the other hand, non-wired supply of fuel types like oil, wood,and pellets are purchased by the owner of the building. Nevertheless, it may be plausible that households choose the main heating fuel source or energy provider based on which billing cycle they offer - although I lack even anecdotal evidence to support this source of selection bias.

Table 2 summarizes the share of buildings observed to have billing accounts that end during different months in 2008, in a data sample of over 250,000 buildings. With $59 \%$ of properties using high calorific natural gas fuel for heating, natural gas is the most common fuel type, and most of the bills are calendar year bills that start in January and end in December. This is also the case for properties supplied with district heating.

The column indicating "August to February" in Table 2 reports the share of buildings that were assigned to billing cycles that start billing during or the beginning of the heating season. This column shows that the large majority of the bills are settled during the heating season for all fuel types except heating oil. For properties using heating oil, the billing cycle depends on the purchase of the fuel, which happens often during the summer months. About $40 \%$ of the buildings receive their bills during or beginning of the non-heating summer months. Moreover, about half of the buildings using heating oil are not on the calendar year billing cycle.

Although the billing cycle assigned to a building is largely a function of heating fuel type, it may still be correlated with the building attributes and demographic composition that affect energy consumption. Even though households do not choose the billing cycles and are also not able to

\footnotetext{
${ }^{8} \mathrm{~A}$ measure of disposable income - "The variable purchasing power reflects the household income. It comprises information on labour supply, capital wealth, rental and leasing income minus taxes and social security contributions, including social transfers such as unemployment benefits, child-allowances and pensions." (Breidenbach and Eilers, 2018)

${ }^{9}$ This statement is based on an email exchange with the data provider. I show in the paper that the assignment of billing cycles is further correlated with building size. For natural gas buildings, newer buildings were more likely to have calendar year accounts.
} 
manipulate the assignment over time, households do choose where to live. It may be that, for example:

- more energy-saving or poorer households choose to live in larger buildings (with more apartment units), and

- the energy-efficiency attributes of buildings differ by size of the building.

Similarly, more energy-consuming households might choose to live in neighborhoods or zip codes with more one-family or two-family homes and fewer multi-apartment buildings. For these reasons, it will be important to condition on residing within a particular locale (state or PLZ zip code) and building type. Conditional on the building size and residing in a particular locale, the assignment of the billing cycle is plausibly exogenous to household decisions or behaviour.

In Tables 3 to 5, I present the distribution of billing cycles by building size (up to 10 apartments) for properties fired with oil, natural gas, and district heating respectively. Table 3 shows that calendar year billing (accounts that end in December) increases significantly with building size, while the share of bills that end during April to June is relatively stable. Table 4 gives information for properties fired with natural gas fuel - the share of calendar year billing increases significantly with the billing size. Larger buildings are more likely to have annual billing cycles that end during December, but this is not the case of district heating properties as seen in Table 5. The share of summer accounts is actually increasing with building size, while the share of calendar year accounts stays constant. Generally, I find that the incidence of non-calendar year billing is not stable as a function of building size.

I focus the main analysis on properties using heating oil, because the share of summer billing accounts is significantly higher, irrespective of building size - minimizing selection bias concerns ${ }^{10}$.

I test whether I observe (quasi-) random assignment on one of the main determinants of heat energy consumption, price per unit of consumption (kWh) by heating energy type. Table 6 reports t-tests of differences in means using simple regressions with fixed effects for the starting year and building size. To check for differences in means by fuel type, I regress fuel price (euro cents per $\mathrm{kWh}$ ) on the starting month of billing assigned for all buildings and also limit the sample to buildings with less than 11 apartments. The omitted month is January, the starting month for calendar year billing, the control group. The first row of coefficients reports the mean price per energy unit incurred by the buildings in the control group.

For each of the fuel type considered, I find statistically significant differences in the mean price of energy for the majority of billing account types in the treatment group, compared to prices faced by buildings on the calendar year cycle. However, the reported coefficients show that these differences are very small in magnitude. There does not seem to be any economically significant variation in prices across billing cycles. Given the large number of observations, it is perhaps not surprising that I am able to detect such small differences in average prices.

For the main analysis in the next section, I use properties that use oil as heating fuel. Table 7 presents mean values of variables of interest for all oil-fired properties. There are clear statistical differences in the building attributes measured by the number of apartments in column 4 and the size of apartments (average heated square meter living space) for other billing cycles. Buildings with calendar year billing (January start) are larger on average, with more than 7 apartments

\footnotetext{
${ }^{10}$ In Section 9 I show that the results also hold for the other fuel types. In particular, I find that natural gas buildings with calendar year billing are newer and thus more energy-efficient. After I control for building-level thermal insulation standards, I confirm the results drawn from the sub-sample of heating oil buildings.
} 
per building, compared to other billing cycles. I measure the outcome variable (heat energy demand) using kWh units demanded per heated square meter living space and estimate the salience effect within building size.

In the analysis that follows, I only consider heating bills measuring consumption for 365 or 366 days. I do not delete any observations that have missing values for any of the variables used in the analysis or remove outliers for consumption, prices, living space, or number of apartments. Nevertheless, repeating the empirical analysis after doing so does not change the results $^{11}$. Moreover the analysis can be replicated using an older billing panel, spanning years 2003 to $2012^{12}$.

\section{Empirical Design}

\section{$5.1 \quad$ Model}

The main empirical approach identifies the heat energy demand response of buildings that have summer billing accounts ${ }^{13}$ versus buildings that are billed for the more common calendar year billing period ending in December. After conditioning for heating fuel type and building size, whether a building receives the summer billing account is seemingly random - I will put this to the test.

I use the following baseline regression to estimate the average treatment effect of summer billing on heat energy demand:

$$
y_{i t}=\alpha_{0}+\alpha_{1} \mathrm{May}_{i t}+\alpha_{2} \mathrm{June}_{i t}+\alpha_{3} \mathrm{July}_{i t}+\delta \text { price }_{i t}+\gamma_{\text {size }}+\lambda_{t}+\epsilon_{i t}
$$

where $y_{i t}$ denotes natural log of annual energy units consumed (kWh) per sqm by building $i$ during the billing periods that started in year $t$.

- $\operatorname{May}_{i}=1, \mathrm{June}_{i}=1$, and $\mathrm{July}_{i}=1$ indicate that that a building has a billing account that starts in May, June, or July respectively.

- price $_{i t}$ captures the fuel specific-price per $\mathrm{kWh}$ unit of energy consumed.

- $\gamma_{\text {size }}$ captures the fixed effects for the size of buildings (number of living units or apartments)

- $\lambda_{t}$ are fixed effects for the year in which billing starts and $\epsilon_{i t}$ the error term, clustered at the building level.

To improve upon the baseline estimates, I will further include two weather covariates: (1) the sum heating degree days (HDD) experienced in each zip-code for the 12 months during each billing period, and (2) the number of heating degree days experienced in each zip code in the first three month of the billing period. I include the 12 month HDD as a control because, by design, heating bills from different billing cycles do not cover the exact same 12 months. Although heating bills from different billing cycles do not cover the exact same 12 months, the

\footnotetext{
${ }^{11}$ See Appendix: Figure A2 for a plot of the trimmed distribution of the dependent variable.

${ }^{12}$ Additional results are available by request.

${ }^{13}$ I focus on the consumption response of billing cycles that start during the specific months of May, June, and July because of the high incidence of billing during these months as shown in Table 3 . The months in Table 3 correspond to the month in which billing ends. Thus, if the bill ends in April, the next bill for the same building starts in May.
} 
12-month rolling sum does not vary significantly across billing cycles as compared to the 3-month rolling sum.

In the last two columns of Table 1, I show that the 12-month rolling sum of heating degree days do not differ significantly across billing cycles, but half the share of the total 12-month sum is experienced in the first three months when billing starts in November, December, and January. More importantly, the share of annual heating degree days experienced in the first 3 months post-billing is close to zero for billing cycles that start in May, June, and July. For this reason, I also include the 3-month intensity of heating degrees days after the receipt of a bill as a covariate. This controls for the fact that the salience of costs may be lower (higher) if the three months following billing are particularly warm (cold) in a given year.

In a nutshell, I identify the salience effect of costs or bills on energy consumption by analysing differences in energy consumed per unit of space between buildings using oil as heating fuel that (naturally) received different billing cycle treatments.

\subsection{Results}

Results reported in Table 8 show the average response of heat energy consumption for oilfired buildings treated with May to July billing accounts, relative to calendar year billing. All specifications include fixed effects for building size. Column 2 controls for the price of heat energy per kWh. Column 3 adds year fixed effects to control for any annual shocks to consumption that are common to all buildings. Column 4 adds the 12 month HDD weather covariate. Column 5 estimates the effect within the same building size in the same German state, while Column 6 adds differences in purchasing power per household at the zip-code level. The model in Column 7 estimates using zip-code level fixed effects and Column 8 adds the 12 month HDD covariate.

The estimated coefficients are consistently between 2 and 4 percent approximately and highly statistically significant. Table 9 repeats the exercise in Table 8, after limiting the sample to oilfired buildings with up to 10 apartments. The magnitudes and the significance of the estimated average treatment effects appear to be stable, and thus not sensitive to the inclusion of larger buildings that are less common in the German population of buildings using heating oil. These findings already provide strong evidence that consumers billed during summer months overconsume energy, likely because of consumer inattention to heating costs.

\subsection{What drives (in)attention?}

I probe whether the degree of salience bias in consumption is sensitive to recorded heating degree days, which is a baseline measure of how much heat energy a building requires. In Table 10, I estimate how the salience effect varies with an increase of 100 heating degree days recorded in the starting first to six months of the billing cycle. The coefficients on the interaction terms are highly statistically significant in the first three columns, highlighting that the sum of heating degree days in the first three months matter the most. An increase of 100 heating degree days experienced in the first month, immediately after billing, causes the rate of over-consumption to fall by 1.8 percentage points. The coefficients on the interactions indicate that salience of bills improves with heating degree days, but at a rate that is highest in the first month and decreasing as time since billing elapses.

In Table 11, I disaggregate the interaction effect with the annual sum of heating degree days to show exactly how the salience of heating costs varies over the 12 month heating period. 
Coefficients on the first three interaction terms show that attention to the heating bill is effective in the first three months. In contrast, more heating needs after the third month of the billing cycle leads to more salience bias in energy consumption.

This section provides supporting evidence that (1) households are indeed more attentive to costs when heating needs increase, and (2) attention takes place in the first three months (of the billing cycle), after which salience of costs has faded significantly. This suggests further that to maximize energy-savings, calendar year billing may still be sub-optimal as the benchmark. Given that the heating season lasts longer than three months, households that are informed of energy expenses at least twice during the winter heating season may be comparatively better off.

\subsection{Cost Salience}

Why do billing cycles make such a significant difference to annual heat energy demand? Given that attention diminishes with time, the temporal gap between the receipt of the heating bill and the heating season would lead to insalience of energy costs I ascertain that the results for all billing cycles are indeed consistent with this insight, particularly affecting those households billed during the summer.

I use the most conservative model in column 8 from Tables 8 and 9 , and now include a dummy for each possible billing cycle observed in the sample. Table 12 shows in the first column that the estimated effects on energy consumption for buildings assigned to the peak summer months of May, June, and July billing accounts remain positive and statistically significant. Controlling for the three-month sum of heating degree days post-billing in the second column, the salience effects almost double in size to between 5 and 7 percent. Now above-optimal energy consumption is not only limited to summer months of May to July. Relative to the calendar year billing period, buildings that are billed during the spring and autumn months of April, August, and September, also consume on average significantly more than those with calendar year billing. This implies that consumer attention to billing is highest during billing months that are followed closely by cold-weather months that require heating, when households can react to cost signals. On the other hand, responsiveness to heating expenses are low during off-heating months, because salience is diminished considerably.

Coefficients on energy demand for the other treatment billing cycles (February, March, October, November, and December) are not statistically significant. Given the dearth of observations for accounts billed during non-summer months, this result may be due to lack of statistical power in estimation. Nonetheless, the pattern consistently indicate that insalience of energy costs is less of a concern during months that require heating. See Figure A3: Plot A for a visual representation of the regression results in columns 1 and 2 .

Overall, the results suggest that households are most inattentive to annual heating bills that are received during the summer. They tend to react to costs in the few months post-billing and unable to respond to the heating costs billed during the summer because heating choices take place during the winter - by then, the heating bill has become less relevant to household expenses. I further address the strength of this mechanism in the next subsection. 


\subsection{Water Heating}

For the majority of the buildings, heating bills cover costs incurred for water heating, in addition to space heating. Although energy consumed for hot water is a smaller share of total annual energy costs, households could react to costs on bills by adjusting the use of hot water instead. Residential demand for energy to heat water is less seasonal than that for space heating, however. Households that are indeed paying attention to bills during the summer months may react by adjusting (disproportionately) the amount of energy they consume for water heating, in the shower and in the kitchen, for example. This would potentially bias the main results had I considered total energy consumption. To test for consumer inattention, I considered energy consumed for space heating independently.

Now I check the extent of consumption adjustments via water heating. I limit the sample of buildings to only those that are billed for both space and water heating, and estimate the preferred equation on energy demand for both space and water heating (in kilowatt hours per square meter of living space). In the third column of Table 12, I confirm the main quantitative findings for space heating.

In the fourth column of Table 12, I directly investigate whether the timing of bills affects energy consumed for heating water. Indeed, I find evidence that households billed during the off-heating months reduce energy demand for heating water. More importantly, this serves as a placebo test for the presumed salience mechanism in determining annual heat energy demand. I interpret this as providing strong evidence that the temporal distance between bills and the winter season is the main driver behind the salience bias in energy consumption for space heating - leading consumers to demand more energy on net. See Figure A3: Plot B for a visual representation of the regression results in columns 3 and 4 .

In the last column of Table 12, I estimate the preferred equation for buildings billed only for space heating. As expected, I find that salience bias in heat energy consumption is more prevalent. Without the option to adjust water heating, results suggest that households consume significantly more heat energy than the control group when billed in the spring months of March and April as well.

\section{Distributional Effects}

Often we are interested not only in the average treatment effect (ATE) for a population, but also the conditional average treatment effects (CATE). More specifically, we may also be interested in the spatial disaggregation of the average effect to understand the socioeconomic distribution of the costs and benefits of policy recommendations.

In this section, I take advantage of this empirical setting to investigate whether salience effects of heating bills varies with the regional heterogeneity in Germany. It is possible to do so because the natural experiment of billing cycles applied nationwide. Here I consider specifically whether the magnitude of the average treatment effect varies meaningfully with the rate of unemployment, measured at the zip code level. 


\subsection{Unemployment Disparities}

Is the treatment effect higher for communities that experience higher unemployment rates? ${ }^{14}$ To estimate the heterogeneity in the ATE with respect to the unemployment rate, I first create terciles of the unemployment rate distribution and then proceed to estimate the preferred specification for oil buildings separately for the terciles.

Table 13 presents descriptive statistics of key variables discussed in this paper by terciles of the unemployment rate in 2009 for houses using oil for heating fuel. As expected the communities in the top tercile have on average lower purchasing power per household, more likely to be living in the East of Germany, and in larger multi-apartment buildings.

\subsection{Subgroup Treatment Effects}

Under the reasonable assumption that poorer households with cash constraints tend to be more attentive year-round to costs and billing information, I would expect that the receipt of bills during low-usage months (when salience of energy consumption costs is diminished) would not induce poorer households to over-consume as much as households that are economically more secure (lower unemployment rates).

Table 14 may suggest the opposite of my hypothesis. The first column estimates the conditional average treatment effects for buildings that are located in zipcodes in the first tercile with mean unemployment rate of $2.7 \%$. The second column estimates the CATE for the second tercile with mean unemployment rate of $5.0 \%$. The third column presents the findings for the top third of the unemployment rate distribution with mean unemployment rate of $9.9 \%$. Finally, the last column produces the average treatment effect for the full distribution of the unemployment rate for comparison purposes. In general, there is suggestive evidence for treatment effect heterogeneity - salience bias during the summer months is higher in poorer socioeconomic neighborhoods. However, this effect heterogeneity seems to be driven by fixed differences between the terciles ${ }^{15}$.

At any rate, heating costs are a higher share of disposable income for households with tighter budgets and thus there exists distributional concerns as a consequence of billing cycles that end during the summer. If it is indeed the case that they are more affected by consumer inattention to heating bills, then the adverse welfare implication of salience bias is compounded.

\section{Robustness}

In the next paragraphs, I test the robustness of the main results for building using heating oil. In particular, I want to rule out the possibility that the results are driven by an unobserved confounding factor. That is, it should not be the case that buildings that are on the calendar year billing cycle are somehow different from the other buildings in some unobserved dimension that may be correlated with energy consumption. For example, there may be concerns that calendar year billing cycles apply to more energy-efficient buildings and/or are chosen by more energy-saving households.

\footnotetext{
${ }^{14}$ Here I make the implicit assumption that buildings located in zip codes with high (low) unemployment rates are home to households that experience high (low) unemployment.

${ }^{15}$ Poorer households tend to live in more energy-inefficient buildings and have cash-constraints, for instance. Based on data from energy performance certificates for the sub-sample of buildings using heating oil, buildings observed in zip codes with higher unemployment rates were on average older and less likely to meet the 1995 thermal insulation standards.
} 


\subsection{Heating vs. Non-Heating Months}

To check this, I exclude buildings billed for the calendar year from the sample of buildings using oil. Then I pool non-heating (summer) and heating months to redefine treatment and control groups more flexibly. Now the control group contains all buildings with billing periods that start in September, October, November, December, February, and March. Note that now I cluster the standards errors at the zip code level to further allay concerns.

Table 15 presents evidence on the robustness of the main results. The first two column report the average treatment effect for buildings billed during the summer months of May to July. In the last two columns, I add April and August to the treatment group. The average treatment effect is about 4 percent over-consumption due to poor salience of heating bills during the summer. These results support the validity of the main estimation results.

\subsection{Energy Performance Scores}

There might still remain the concern that for some reason, buildings that are newer and thus more energy-efficient (due to building codes or simply better technology, for instance) are billed during the winter heating season. I limit the sample of buildings using heating oil to a subset, for which I have information on energy performance certificates. These certificates were issued to the buildings from 2008 to 2018, largely issued in 2008, and I matched them to the primary data on consumption bills (about $40 \%$ of the observations). I further split the sample into classes of building codes ${ }^{16}$ and report the average year of construction by billing cycles. Table 16 shows that the mean age of buildings are almost identical across billing cycles except for buildings built before the building codes were introduced. For building built before 1919, buildings with calendar year billing are newer than average. However, this is not the case for buildings built from 1919 to 1977.

Note that the sample of buildings reporting energy performance scores is possibly more energyefficient than the full sample, because the building owner's decision to produce the EPC is likely correlated with recent energetic-renovations in the past that affect energy consumption of these buildings. And therefore, the building year is not a precise or complete measure to learn about the energy performance of these buildings.

Moreover, the energy performance score is likely an endogenous explanatory variable in this setting, because majority of energy performance scores ("Verbrauchsausweis") are measured using building-level consumption that took place in the past years (which would include the any effect of consumer inattention to costs and bills due to intermittent and untimely billing - the main thesis of this paper.)

Notwithstanding these important caveats, I redo the main estimation for buildings using heating oil using fixed effects for building codes, and year of construction and reported energy performance score as further controls to check whether average treatment effects are sensitive to the inclusion.

Table 17 shows that differences in these energy-performance metrics measured across billing

\footnotetext{
${ }^{16}$ Energy efficiency regulation in Germany has largely taken the form of building codes, defining the buildingaggregate maximum annual energy requirement per square meter of living space for newly constructed homes. The Heat Insulation Ordinance was first introduced in 1977, amended and made progressively more stringent in 1984 and 1995. It was replaced by the Energy Saving Ordinance in 2002. Note that there were no minimum energy standards for buildings built before 1978 .
} 
cycles do make a difference in the magnitude of the results, but the conclusions of the main results are robust to these conservative specifications. Column 1 shows the preferred model on the subsample of buildings with energy performance certificates. Column 2 adds fixed effects for building code regulation which controls for differences in the efficiency standards based on the date of construction. The model in Column 3 further includes the year of construction as a covariate. Column 4 uses the minimum reported performance score irrespective of the year when the EPC was issued, while in column 5 the sample is limited to only those buildings with performance certificates issued in the year 2008.

\subsection{Buildings Built Before 1978}

In order to further limit any bias arising from differences in energy-efficiency of buildings on different billing cycles, I focus only on the subset of observed buildings that were built before 1978, and therefore did not fall under any thermal insulation standards during construction.

Table 18 reports the ATE by type of buildings (two-family houses, 3 to 6 multi-family buildings, 7 to 12 multi-apartment buildings, and buildings with 13 apartments units or more). Results indicate the energy consumption by two-family homes is even more sensitive to the timing of bills - with salience bias up to 15 percent for bills starting in the summer month of June. This may be a particularly noteworthy result because close to half the building stock (owned and rented) by German families are one-to-two family unit buildings (Destatis, 2016).

\subsection{Munich and Stuttgart}

Here I limit the analysis to buildings using heating oil in the large urban cities of Munich and Stuttgart for two main reasons:

- the share of buildings with calendar year billing cycles is less than $50 \%$ (41\% in Stuttgart and $46 \%$ in Munich). The corresponding share in the other major German cities of Berlin, Hamburg, Cologne, Frankfurt (Frankfurt am Main) are much larger (60 to $70 \%$ ).

- the housing supply shortages are particularly acute in Stuttgart and Munich, and the associated market tightness means that any bias arising due to household selection into different billing cycles is plausibly absent.

To identify the urban regions of Stuttgart and Munich, I limit the sample to buildings located in their respective regional planning regions ("Raumordnungsregionen or ROR"). Number 810 represents Stuttgart (3,850 buildings) and number 910 (3,417 buildings) represents Munich).

Table 19 presents the results for buildings located in these regions. Estimates indicate a large salience effect of 6 percent for buildings billed during the summer. Stuttgart and Munich fall in the lowest tercile of unemployment rates and over-consumption of heat energy exists, when billing occurs during months that are marked by the lowest share of total annual heating degree days in the 3 months post-billing.

\section{Long-term Investments}

Thus far, I have remained silent on how building-level investments in energy-efficiency technology (thermal insulation or heating fuel efficiency in this context) may have been affected over the long-run by enduring differences in the salience of heating bills and thus energy cost expenditures. 
I address this topic directly in this section and identify the relative importance of inattention to energy-efficiency decisions for residential apartment buildings - one of the first estimates in the literature (Gerarden et al., 2017).

Keeping all else equal, I expect that homes that incur annual higher expenditures for energy consumption to have higher incentives to invest in thermal efficiency to save on energy costs. In the previous sections, I show that apartment buildings that are billed during the summer season are prone to above-optimal consumption levels, which translates into higher annual costs of home heating. Given this backdrop, I empirically test whether persistent positive exogenous shocks to energy costs and thus financial incentives, led to statistically significant differences in investments by building owners in energy-efficiency technology.

I perform this test using data from energy performance certificates that were issued between 2014 and 2019 to buildings using heating oil and constructed before 1978, i.e. they were not subject to building standards. This allows me to plausibly argue that any detectable differences in thermal insulation standards are due to investments in renovations post-construction and not due to federal building codes.

Table 20 provides summary statistics of the sample. Using energy performance certificates issued starting 2014, I observe data on (1) the year of construction or year of latest renovation of key building component that are associated with heat energy efficiency, and (2) whether the building component meets efficiency standards regulated under WSVO 1995 (building-level thermal insulation standards).

Panel A shows that the mean age of building is statistically identical (p-value 0.1774) across treatment and control groups. This is also true for the basement ceiling, but fails for all other thermal-insulation features of the roof, loft, outer wall surface, and windows.

Panel B shows even more interesting descriptive statistics. The first column under "Overall" indicates how may of the five building components (roof, loft ceiling, outer wall, windows, and basement ceiling) were certified to meet thermal insulation standards under WSVO 1995. On average, buildings with summer billing accounts were associated with a higher share of key building components that met the 1995 thermal-insulation standards.

Now I test my hypotheses of differences in energy-efficiency investments in a more systematic manner - using a regression model that controls for observable characteristics of buildings and zip code/location. I use the following baseline linear probability model with fixed effects to estimate differences in heating-efficiency investments across billing cycles:

$$
y_{i}=\alpha+\beta \text { May to } \text { July }_{i}+\delta \text { Year Built }_{i}+\gamma_{\text {Size }}+\theta_{\text {PLZ }}+\lambda_{t}+\epsilon_{i}
$$

where $y_{i}$ in an indicator for whether each of the seven measures (overall, heater, roof, outer wall, loft, windows, and basement) of building $i$ meets the thermal insulation standards set out in WSVO 1995 regulation, at the time of certification. For the heating system, I use the indicator for whether the year of heating system installed is greater or equal to 1995 .

- May to $\mathrm{July}_{i}$ indicates whether the billing cycle (the starting month) associated with the building $i$ started in May, June, or July. The control group is buildings with calendar year accounts.

- Year Built ${ }_{i t}$ captures the year in which the building was newly constructed.

- $\gamma_{\text {Size }}$ and $\theta_{\text {PLZ }}$ capture the building size and zip code fixed effects respectively. 
- $\lambda_{t}$ are fixed effects for the year in which the EPC was issued and $\epsilon_{i}$ the error term, clustered at the zip code level.

Table 21 demonstrates that building owners treated with summer billing cycles invested to retrofit a higher share of the building envelope to meet the 1995 thermal insulation standards, captured by the variable "overall". The estimate of 0.231 translates to a 4.3 percent increase in the share of building components receiving an insulation upgrade that met the 1995 standards. This estimate was likely powered by higher investments in insulating the roof, exterior wall, and windows. The windows components was particularly affected - with an increase of 9 percent share of buildings that received renovation meeting the 1995 insulation standard. I do not find any statistically significant differences in the shares for the loft and basement ceiling, however.

Although the economic significance of these differences in investment rates across billing cycles may not be high, the results in this section do provide some evidence that long-term financial incentives for energy-efficiency do matter, and owners of multi-apartment buildings responded to differences in expected returns to investments in energy-efficiency - at least for buildings built before 1978, associated with low rates of renovation (Ray and Sunikka-Blank, 2013).

These results show that salience of costs affect not only short-term consumption behaviour of tenants/residents, but also feed into long-run investment decisions of building owners. Any energy-efficiency gaps, due to lack of investments into heat energy efficiency, for instance, can be optimally bridged by drawing the user's attention to true energy costs - by improving the salience of billing information.

With respect to salience bias in energy consumption, the results in this section further imply that the short-run estimates are likely even higher, all else equal. The results captured in this paper capture the effect of attention bias over the long-run, after learning and investment adjustments have taken place as result of the treatment. I confirm this in Section 9.3 by considering a sample of buildings that are as similar as possible in meeting thermal-insulation standards.

\section{Other Energy Sources}

In this section, I show that the results are not limited to buildings using heating oil.

\subsection{Natural Gas}

I consider buildings that use natural gas as the main heating fuel. Interestingly, I find that newer buildings using natural gas were more likely to be on the calendar year billing cycle. In Table 22, I estimate the preferred model on the full sample and find that all billing accounts were associated with higher heat energy demand relative to the control group of calendar year billing. This pattern re-emerges once I limit the sample to those buildings with energy performance certificates in column 2 .

I account for this bias in treatment assignment using fixed effects for building codes that were applicable by year of construction ${ }^{17}$. In Columns 3 and 4 , I show that buildings billed during the off-heating season are subject to consumer inattention to costs during the winter. The results

\footnotetext{
${ }^{17}$ Alternatively: I limit the sample of buildings to those built before 1978 and recover a pattern of overconsumption, consistent with non-salience of energy costs during the non-heating months. The estimates (available by request) are of higher magnitudes compared to estimated treatment effects for all buildings. More importantly, Table 22 show that salience bias in heat consumption exists, irrespective of building age.
} 
are robust to controlling for the minimum energy performance scores. There may still exist a positive likelihood for selection bias if older buildings that were renovated and switched to natural gas fuel were more likely to be assigned the calendar year billing cycle. For this reason, I consider a sample of buildings that are comparable on all observable energy efficiency measures in Section 9.3.

\subsection{District Heating}

I further consider buildings that used district heating and to improve precision of my estimates I pool the non-heating months of May, June, and July. Note that the control group includes only calendar year billing. Similar to buildings heated with natural gas, I find some bias in billing cycle assignment by age of the building (see Table 23). After adding in the fixed effects for building codes, however, the estimate for salience bias in energy consumption is robust to further controls.

\subsection{Buildings with WSVO 1995 Standard}

Finally, I construct a subsample of buildings that meet the building standards mandated under the thermal insulation regulation of 1995 (WSVO 1995). Because the average age of buildings in the full sample is 1967 and over $80 \%$ of the buildings were built before 1995 ("Altbau"), achieving the 1995 standard is arguably a suitable benchmark for good energy performance of buildings ${ }^{18}$.

I classify a building to meet WSVO 1995, if it was certified that all five building components (the roof, loft ceiling, outer wall, windows, and basement ceiling) meet the 1995 minimum energysaving standards. Using this subsample, I seek to examine buildings that are as comparable as possible in terms of energy-efficiency investments and insulation performance. I pool nonheating billing months of May to July to form the treatment group, while calendar year billing remains the control group. The result that follow are robust to clustering at the zip code level.

Table 24 presents the findings. In column 1, I estimate the preferred equation for buildings using natural gas that meet the 1995 thermal insulation standards. In the next column, I further account for any remaining differences in energy performance of buildings by controlling for the year of construction, year of the heating system, along with fixed effects for building energy-standards. The rate of over-consumption due to non-salience stays close to 9 percent. In the last column, I expand the sample by including buildings using heating oil and district heating, while adding fixed effects for fuel type, and find approximately the same quantitative result.

I interpret these results as strong evidence that over-consumption due to poor salience of heating bills is pervasive and not limited to buildings that use heating oil or to buildings with poor energy-efficiency standards. I conclude that there exists economically significant potential to conserve energy via behavioural changes using appropriately-timed bills to improve salience of energy costs.

\section{Qualifications and Extensions}

Following are some caveats to the empirical results:

\footnotetext{
${ }^{18} \mathrm{I}$ am unable to consider stricter thermal insulation standards due to lack of data.
} 
I do not observe directly the level of attention households pay to bills and how this differs by month of bill receipt. Moreover, I do not know the exact date building managers distribute the bills to the residents - this is less of an issue, however, for small apartment buildings and homes that use heating oil.

The belief about the exogeneity of billing periods or cycles is central to removing unobserved selection bias in estimating treatment effects. The setup does not allow to fully control for household-specific factors. However, given that I measure building-level consumption, I do not expect households living in buildings with summer accounts versus winter accounts to be systematically different on the aggregate (in income and preferences for heating, for example), conditioning for building characteristics and location.

One important area of future research would be to quantify the extent to which split incentives between landlords and tenants led to differences in long-term efficiency investments. Do landlords with tenants underinvest compared to home-owners, all else equal? To answer this question, one can replicate the analysis in this paper for a data sample of single-family homes, distinguishing between owner-occupied and rented-homes.

\section{Conclusion}

By exploiting the billing cycle assignment in a large scale natural experiment in Germany, I estimate a causal over-consumption of heating energy by buildings that are billed during the summer months, and thus are treated with low salience of energy costs. Empirical results in this paper are theory consistent. Effective attention to costs take place in the few months immediately after billing. Consequently, consumers billed for heating during off-winter months are subject to consumer inattention, leading to their perceived cost of consumption to be lower - resulting in above optimal heat energy demand. Results demonstrate that buildings that are billed for space heating during the summer consume on average up to 9 percent more than those that are billed for the more common calendar year billing cycle.

This research highlights the importance of improving the salience of information on energy prices and consumption to encourage consumer attention and alter household behaviour. Engaging energy users with bills during high-consumption events has significant potential to achieve energy savings in the building sector, both in the short- and long-run, without additional investments for technical building efficiency.

This paper further examines whether differences in consumer inattention to energy costs had a long-term impact on technology choices and investments. I find evidence that building owners reacted to higher annual heating expenditures by investing in long-term thermal insulation of buildings. This result is evidence that under-investment (the energy-efficiency gap) in heat energy-efficiency due to the split-incentive problem between landlords and tenants may not be as high as previously thought. These decisions to retrofit were driven by distortions in financial incentives, due to salience bias in household consumption, rather than energy-efficiency shortcomings of buildings billed during the summer. Notwithstanding, these results illustrate that investments in energy upgrades for existing buildings did respond to energy cost shocks.

In Germany, the heating sector is primarily powered by fossil-fuels and accounts for $25 \%$ of the final energy consumed, of which about $70 \%$ is consumed by the residential sector (AGEB, 2018). The results in this paper indicate that the current billing system that is used for the vast majority of buildings in Germany is not optimal for reaching energy and environmental policy 
targets. Ultimately, those households that want to save on bills or conserve heating energy must know the heating costs, with timely information or costs of attention to be as low as possible. This is likely to be increasingly important given the recent discussion of a $\mathrm{CO}_{2}$ price on the heating sector (mainly for buildings) in Germany. Providing homes with heating bills during the peak of winter (relevant information at the relevant time) is arguably not more costly than status-quo, but it does have the high potential to reduce energy consumption from the household sector. 


\section{References}

AGEB (2018). Anwendungsbilanzen für die Endenergiesektoren in Deutschland in den Jahren 2013 bis 2017. Report, AG Energiebilanzen e.V. (available online, in German).

Breidenbach, P. and Eilers, L. (2018). RWI-GEO-GRID: Socio-economic data on grid level. Jahrbücher für Nationalökonomie und Statistik, 238(6):609-616.

Chetty, R., Looney, A., and Kroft, K. (2009). Salience and taxation: Theory and evidence. American Economic Review, 99(4):1145-1177.

DellaVigna, S. (2009). Psychology and economics: Evidence from the field. Journal of Economic Literature, 47(2):315-372.

DellaVigna, S. and Pollet, J. (2009). Investor inattention and friday earnings announcements. The Journal of Finance, 64(2):709-749.

Destatis (2016). Bauen und Wohnen. Mikrozensus - Zusatzerhebung 2014. Report, Statistisches Bundesamt, Wiesbaden. (available online, in German).

Finkelstein, A. (2009). E-ztax: Tax salience and tax rates. Quarterly Journal of Economics, 124(3):969-1010.

Gerarden, T. R., Newell, R. G., and Stavins, R. N. (2017). Assessing the energy-efficiency gap. Journal of Economic Literature, 55(4):1486-1525.

Gilbert, B. and Zivin, J. G. (2014). Dynamic salience with intermittent billing: Evidence from smart electricity meters. Journal of Economic Behavior \& Organization, 107:179-190.

Jessoe, K. and Rapson, D. (2014). Knowledge is (less) power: Experimental evidence from residential energy use. American Economic Review, 104(4):1417-1438.

Pon, S. (2017). The effect of information on TOU electricity use: an irish residential study. The Energy Journal, 38(6):55-79.

Prest, B. C. (2020). Peaking interest: How awareness drives the effectiveness of time-of-use electricity pricing. Journal of the Association of Environmental and Resource Economists, 7(1):103-143.

Ray, G. and Sunikka-Blank, M. (2013). A Critical Appraisal of Germany's Thermal Retrofit Policy: Turning Down the Heat. London: Springer.

RWI and microm (2020). RWI-GEO-GRID: Socio-economic data on grid level (wave 9). Version: 1. RWI - Leibniz Institute for Economic Research. Dataset. http://doi.org/10.7807/microm:V8.

Sexton, S. (2015). Automatic bill payment and salience effects: Evidence from electricity consumption. The Review of Economics and Statistics, 97(2):229-241.

Singhal, P. and Stede, J. (2019). Heat monitor 2018: Rising heating energy demand, thermal retrofit rate must increase. DIW Weekly Report, Volume 9, Issue 35/36, 303-312.

Tiefenbeck, V., Götte, L., Degen, K., Tasic, V., Fleisch, E., Lalive, R., and Staake, T. (2018). Overcoming salience bias: How real-time feedback fosters resource conservation. Management Science, 64(3):1458-1476. 
Wichman, C. (2017). Information provision and consumer behavior: A natural experiment in billing frequency. Journal of Public Economics, 152:13-33. 


\section{Tables}

Table 1: Heating Needs During the Year

\begin{tabular}{lcccc}
\hline \hline & & \multicolumn{3}{c}{ Heating Degree Days (HDD) } \\
\cline { 3 - 5 } Month & Mean Temperature & Monthly & 12-month sum & 3-month sum \\
\hline \multirow{2}{*}{ January } & 0.52 & 449.0 & 2426.2 & 1184.1 \\
February & 0.68 & 404.2 & 2424.5 & 911.4 \\
March & 4.33 & 330.9 & 2414.3 & 590.1 \\
April & 9.26 & 176.3 & 2412.0 & 284.9 \\
May & 13.23 & 82.9 & 2409.8 & 118.5 \\
June & 16.59 & 25.7 & 2414.3 & 48.2 \\
July & 18.60 & 9.9 & 2414.3 & 79.1 \\
August & 17.82 & 12.6 & 2414.5 & 245.2 \\
September & 14.09 & 56.6 & 2414.4 & 529.0 \\
October & 9.40 & 176.0 & 2413.6 & 878.1 \\
November & 5.12 & 296.4 & 2404.6 & 1149.3 \\
December & 1.92 & 405.6 & 2405.8 & 1247.0 \\
\hline Total & 9.30 & 202.2 & 2414.0 & 605.4 \\
\hline \hline
\end{tabular}

Note: The second column reports heating degree days during each month, calculated as the total sum of differences between the daily mean temperature and the heating limit of 15 degree Celsius on days with recorded mean temperatures less than 15 degrees. The values are calculated by the author using daily observations from 20030101 to 20181231 at 204 nearest weather stations to 8303 zipcodes in Germany. In the mapping used, average distance between zip code and nearest weather station is $18.3 \mathrm{~km}$, with standard deviation of $10.4 \mathrm{~km}$, minimum and maximum distance of $0.076 \mathrm{~km}$ and $59.86 \mathrm{~km}$ respectively. Source: Deutscher Wetterdienst (DWD).

Table 2: Incidence of Billing Accounts by Fuel Type

\begin{tabular}{lcccc}
\hline \hline Fuel Type & March - July & August - February & December & Share \\
\hline Natural Gas H & 0.16 & 0.84 & 0.68 & 0.59 \\
Oil & 0.39 & 0.61 & 0.49 & 0.32 \\
District Heating & 0.15 & 0.85 & 0.76 & 0.08 \\
Natural Gas L & 0.00 & 1.00 & 0.21 & 0 \\
Other & 0.24 & 0.76 & 0.64 & 0.01 \\
\hline Total & $23 \%$ & $77 \%$ & $62 \%$ & \\
\hline \hline
\end{tabular}

Note: The first two columns show the share of buildings in year 2008 with annual heating bills ending in March to July and August to February. The December column indicates the share of buildings with accounts ending in December (calendar year billing). The last column reports the share of buildings by heating fuel type observed in 2008, sample of over 250,000 buildings. "Other" fuel types consist of LPG, pellets, electricity, wood, coal, brown coal, steam, coke, and others. 
Table 3: Billing Cycles by Building Size - Heating Oil Homes

\begin{tabular}{lccccccccc}
\hline & \multicolumn{7}{c}{ Number of Apartments/HH } \\
\cline { 2 - 9 } End of Billing & 2 & 3 & 4 & 5 & 6 & 7 & 8 & 9 & 10 \\
\hline \multirow{2}{*}{ January } & 2.2 & 1.6 & 1.5 & 1.1 & 0.8 & 0.9 & 0.4 & 0.6 & 0.6 \\
February & 2.3 & 1.6 & 1.6 & 1.4 & 0.6 & 0.9 & 0.8 & 0.6 & 0.4 \\
March & 3.6 & 3.1 & 2.3 & 2.0 & 1.8 & 1.7 & 1.5 & 1.2 & 0.7 \\
April & 5.3 & 5.0 & 4.3 & 4.1 & 3.7 & 4.3 & 4.0 & 5.3 & 5.3 \\
May & 23.2 & 27.5 & 26.4 & 22.9 & 22.2 & 19.7 & 17.9 & 18.3 & 14.5 \\
June & 8.2 & 8.1 & 7.2 & 7.0 & 6.2 & 6.3 & 6.6 & 6.7 & 6.6 \\
July & 3.3 & 2.5 & 2.1 & 1.8 & 1.5 & 1.2 & 1.2 & 0.8 & 1.0 \\
August & 3.2 & 2.6 & 2.1 & 2.1 & 1.0 & 1.2 & 1.2 & 0.9 & 1.2 \\
September & 5.2 & 4.3 & 3.6 & 3.8 & 2.6 & 2.8 & 1.6 & 2.4 & 1.5 \\
October & 2.6 & 2.0 & 1.7 & 1.3 & 0.9 & 1.1 & 1.2 & 1.1 & 0.6 \\
November & 1.6 & 1.4 & 1.3 & 1.0 & 0.8 & 0.7 & 0.8 & 0.9 & 0.5 \\
December & 39.3 & 40.4 & 45.9 & 51.5 & 57.6 & 59.2 & 62.7 & 61.2 & 66.9 \\
\hline April to June & 36.6 & 40.6 & 38.0 & 34.0 & 32.1 & 30.3 & 28.6 & 30.3 & 26.5 \\
\hline \hline
\end{tabular}

Note: The table shows the distribution of billing cycles observed in 2008 for all buildings with up to 10 apartments that use heating oil as fuel.

Table 4: Billing Cycles by Building Size - Natural Gas Homes

\begin{tabular}{lccccccccc}
\hline & \multicolumn{7}{c}{ Number of Apartments/HH } \\
\cline { 2 - 9 } End of Billing & 2 & 3 & 4 & 5 & 6 & 7 & 8 & 9 & 10 \\
\hline \multirow{2}{*}{ January } & 2.6 & 2.7 & 2.2 & 2.0 & 1.3 & 1.8 & 1.5 & 1.6 & 0.9 \\
February & 2.9 & 2.4 & 2.1 & 2.1 & 1.7 & 1.8 & 1.5 & 1.5 & 1.8 \\
March & 4.0 & 3.7 & 3.4 & 2.8 & 2.5 & 2.7 & 2.4 & 1.9 & 2.1 \\
April & 4.4 & 3.9 & 3.6 & 3.0 & 2.8 & 2.6 & 2.3 & 2.2 & 2.5 \\
May & 7.0 & 7.3 & 6.0 & 5.5 & 4.3 & 5.0 & 4.2 & 3.5 & 3.6 \\
June & 5.1 & 5.3 & 4.7 & 4.1 & 3.7 & 4.1 & 3.6 & 3.8 & 3.3 \\
July & 1.8 & 1.5 & 1.3 & 1.2 & 0.9 & 1.0 & 1.0 & 1.1 & 0.9 \\
August & 2.6 & 2.2 & 1.9 & 1.7 & 1.5 & 1.7 & 1.4 & 1.1 & 1.2 \\
September & 8.2 & 7.0 & 6.6 & 5.4 & 5.3 & 4.8 & 4.5 & 3.7 & 3.9 \\
October & 5.3 & 4.5 & 3.9 & 3.2 & 2.7 & 2.7 & 2.0 & 2.1 & 2.1 \\
November & 3.7 & 3.5 & 3.1 & 2.6 & 2.4 & 2.6 & 2.0 & 2.0 & 1.3 \\
December & 52.4 & 56.2 & 61.3 & 66.4 & 70.9 & 69.2 & 73.6 & 75.4 & 76.5 \\
\hline April to June & 16.5 & 16.4 & 14.3 & 12.6 & 10.8 & 11.7 & 10.0 & 9.5 & 9.3 \\
\hline \hline
\end{tabular}

Note: The table shows the distribution of billing cycles observed in 2008 for all buildings with up to 10 apartments that use natural gas as fuel. 
Table 5: Billing Cycles by Building Size - District Heating Homes

\begin{tabular}{lccccccccc}
\hline \hline & \multicolumn{7}{c}{ Number of Apartments/HH } \\
\cline { 2 - 9 } End of Billing & 2 & 3 & 4 & 5 & 6 & 7 & 8 & 9 & 10 \\
\hline \multirow{2}{*}{ January } & 1.7 & 3. & 2.1 & 1.3 & 1.2 & 1.1 & 0.9 & 1.2 & 1.6 \\
February & 1.4 & 1.7 & 1.7 & 1.8 & 1.0 & 0.6 & 1.0 & 1.3 & 1.7 \\
March & 3.1 & 3.3 & 3.1 & 1.9 & 2.0 & 2.3 & 1.9 & 2.3 & 1.6 \\
April & 2.4 & 3.3 & 4.6 & 2.2 & 1.8 & 1.8 & 2.8 & 1.7 & 2.7 \\
May & 4.1 & 4.6 & 3.0 & 5.6 & 5.3 & 3.2 & 4.4 & 5.1 & 3.6 \\
June & 8.0 & 6.5 & 8.7 & 8.0 & 6.8 & 9.8 & 10.4 & 11.7 & 12.0 \\
July & 1.7 & 1.5 & 1.0 & 1.4 & 1.2 & 1.4 & 0.9 & 1.2 & 1.7 \\
August & 2.2 & 2.9 & 1.6 & 2.0 & 1.8 & 1.2 & 1.2 & 1.2 & 1.6 \\
September & 3.1 & 3.5 & 2.9 & 2.8 & 3.8 & 2.5 & 3.7 & 3.6 & 4.9 \\
October & 2.0 & 2.4 & 1.5 & 2.1 & 2.5 & 1.3 & 1.2 & 1.7 & 1.0 \\
November & 2.6 & 1.5 & 0.8 & 1.0 & 0.9 & 1.1 & 1.0 & 0.7 & 0.7 \\
December & 67.8 & 64.8 & 68.9 & 69.9 & 71.8 & 73.7 & 70.6 & 68.2 & 66.8 \\
\hline April to June & 14.5 & 14.4 & 16.3 & 15.8 & 13.9 & 14.9 & 17.6 & 18.5 & 18.3 \\
\hline \hline
\end{tabular}

Note: The table shows the distribution of billing cycles observed in 2008 for all buildings with up to 10 apartments that have district heating. 
Table 6: Balance Test - Differences in Mean Price

Euros per kWh by Month of Billing Start

\begin{tabular}{|c|c|c|c|c|c|c|}
\hline \multirow[b]{2}{*}{ Bill Start } & \multicolumn{2}{|c|}{ Heating Oil } & \multicolumn{2}{|c|}{ Natural Gas H } & \multicolumn{2}{|c|}{ District Heating } \\
\hline & All & Apts $<11$ & All & Apts $<11$ & All & Apts $<11$ \\
\hline Constant & $\begin{array}{c}0.0643 \\
(0.00)\end{array}$ & $\begin{array}{c}0.0643 \\
(0.00)\end{array}$ & $\begin{array}{c}0.0670 \\
(0.00)\end{array}$ & $\begin{array}{c}0.0674 \\
(0.00)\end{array}$ & $\begin{array}{c}0.0961 \\
(0.00)\end{array}$ & $\begin{array}{c}0.0952 \\
(0.00)\end{array}$ \\
\hline February & $\begin{array}{c}-0.0007 \\
(0.00)\end{array}$ & $\begin{array}{c}-0.0007 \\
(0.00)\end{array}$ & $\begin{array}{c}0.0014 \\
(0.00)\end{array}$ & $\begin{array}{c}0.0016 \\
(0.00)\end{array}$ & $\begin{array}{c}-0.0047 \\
(0.00)\end{array}$ & $\begin{array}{c}-0.0037 \\
(0.00)\end{array}$ \\
\hline March & $\begin{array}{c}-0.0003 \\
(0.01)\end{array}$ & $\begin{array}{c}-0.0003 \\
(0.00)\end{array}$ & $\begin{array}{c}0.0008 \\
(0.00)\end{array}$ & $\begin{array}{c}0.0010 \\
(0.00)\end{array}$ & $\begin{array}{c}-0.0055 \\
(0.00)\end{array}$ & $\begin{array}{c}-0.0056 \\
(0.00)\end{array}$ \\
\hline April & $\begin{array}{c}0.0000 \\
(0.89)\end{array}$ & $\begin{array}{c}-0.0000 \\
(0.96)\end{array}$ & $\begin{array}{c}0.0006 \\
(0.00)\end{array}$ & $\begin{array}{c}0.0008 \\
(0.00)\end{array}$ & $\begin{array}{c}-0.0078 \\
(0.00)\end{array}$ & $\begin{array}{c}-0.0071 \\
(0.00)\end{array}$ \\
\hline May & $\begin{array}{c}0.0010 \\
(0.00)\end{array}$ & $\begin{array}{c}0.0008 \\
(0.00)\end{array}$ & $\begin{array}{c}0.0004 \\
(0.00)\end{array}$ & $\begin{array}{c}0.0004 \\
(0.00)\end{array}$ & $\begin{array}{c}-0.0035 \\
(0.00)\end{array}$ & $\begin{array}{c}-0.0000 \\
(0.97)\end{array}$ \\
\hline June & $\begin{array}{c}0.0006 \\
(0.00)\end{array}$ & $\begin{array}{c}0.0006 \\
(0.00)\end{array}$ & $\begin{array}{c}0.0011 \\
(0.00)\end{array}$ & $\begin{array}{c}0.0013 \\
(0.00)\end{array}$ & $\begin{array}{c}-0.0049 \\
(0.00)\end{array}$ & $\begin{array}{c}-0.0051 \\
(0.00)\end{array}$ \\
\hline July & $\begin{array}{c}0.0002 \\
(0.00)\end{array}$ & $\begin{array}{c}0.0002 \\
(0.00)\end{array}$ & $\begin{array}{c}0.0000 \\
(0.97)\end{array}$ & $\begin{array}{c}-0.0003 \\
(0.00)\end{array}$ & $\begin{array}{c}-0.0091 \\
(0.00)\end{array}$ & $\begin{array}{c}-0.0068 \\
(0.00)\end{array}$ \\
\hline August & $\begin{array}{c}-0.0005 \\
(0.00)\end{array}$ & $\begin{array}{c}-0.0005 \\
(0.00)\end{array}$ & $\begin{array}{c}0.0002 \\
(0.44)\end{array}$ & $\begin{array}{c}0.0002 \\
(0.30)\end{array}$ & $\begin{array}{c}-0.0051 \\
(0.00)\end{array}$ & $\begin{array}{c}0.0026 \\
(0.00)\end{array}$ \\
\hline September & $\begin{array}{c}0.0001 \\
(0.34)\end{array}$ & $\begin{array}{c}0.0001 \\
(0.54)\end{array}$ & $\begin{array}{c}0.0004 \\
(0.00)\end{array}$ & $\begin{array}{c}0.0005 \\
(0.00)\end{array}$ & $\begin{array}{c}-0.0059 \\
(0.00)\end{array}$ & $\begin{array}{c}-0.0065 \\
(0.00)\end{array}$ \\
\hline October & $\begin{array}{c}-0.0001 \\
(0.04)\end{array}$ & $\begin{array}{c}-0.0002 \\
(0.01)\end{array}$ & $\begin{array}{c}-0.0005 \\
(0.00)\end{array}$ & $\begin{array}{c}-0.0006 \\
(0.00)\end{array}$ & $\begin{array}{c}0.0030 \\
(0.00)\end{array}$ & $\begin{array}{c}0.0004 \\
(0.65)\end{array}$ \\
\hline November & $\begin{array}{c}-0.0004 \\
(0.00)\end{array}$ & $\begin{array}{c}-0.0004 \\
(0.00)\end{array}$ & $\begin{array}{c}-0.0003 \\
(0.00)\end{array}$ & $\begin{array}{c}-0.0001 \\
(0.17)\end{array}$ & $\begin{array}{c}-0.0089 \\
(0.00)\end{array}$ & $\begin{array}{c}-0.0075 \\
(0.00)\end{array}$ \\
\hline December & $\begin{array}{c}-0.0004 \\
(0.01)\end{array}$ & $\begin{array}{c}-0.0004 \\
(0.00)\end{array}$ & $\begin{array}{c}-0.0001 \\
(0.53)\end{array}$ & $\begin{array}{l}0.0001 \\
(0.47)\end{array}$ & $\begin{array}{c}0.0042 \\
(0.00)\end{array}$ & $\begin{array}{c}0.0021 \\
(0.08)\end{array}$ \\
\hline Observations & 809,754 & 725,829 & $1,630,852$ & $1,270,465$ & 287,809 & 102,721 \\
\hline $\operatorname{Adj} R^{2}$ & 0.416 & 0.414 & 0.028 & 0.032 & 0.026 & 0.023 \\
\hline
\end{tabular}

Note: Table reports coefficients from simple regressions of heating costs incurred per unit of energy (kWh) on the starting month of the billing period, with fixed effects for the year and building size, and robust standard errors. The omitted month is January which corresponds to the calendar year billing cycle, the control group. I discard observations with yearly consumption below $1 \mathrm{kWh} / \mathrm{m}^{2}$ and price per $\mathrm{kWh}$ above 1 Euro $(0.1 \%$ of total). Constant reports the average price per $\mathrm{kWh}$ that was paid by buildings in the control group. p-values are reported in parentheses. 
Table 7: Descriptive Statistics - Oil Units

\begin{tabular}{lcccccc}
\hline \hline Bill Start & $\mathrm{kWh} / \mathrm{m}^{2}$ & Price & \# of Apts & Apt Size & PP per HH & \# of Bills \\
\hline January & 126.31 & 6.47 & 7.21 & 90.04 & 45.15 & 488,921 \\
February & 120.43 & 6.46 & 3.51 & 89.32 & 46.36 & 11,422 \\
March & 119.68 & 6.49 & 3.49 & 91.23 & 46.61 & 12,344 \\
April & 122.08 & 6.54 & 3.99 & 89.51 & 46.49 & 22,495 \\
May & 130.22 & 6.64 & 6.20 & 85.10 & 44.97 & 41,157 \\
June & 127.15 & 6.62 & 4.40 & 83.95 & 45.60 & 167,029 \\
July & 126.76 & 6.63 & 5.47 & 88.44 & 45.77 & 57,592 \\
August & 124.79 & 6.53 & 3.81 & 89.84 & 46.79 & 17,104 \\
September & 121.79 & 6.59 & 3.79 & 91.00 & 46.22 & 17,892 \\
October & 122.52 & 6.57 & 4.12 & 91.11 & 46.07 & 30,972 \\
November & 121.55 & 6.54 & 3.95 & 88.89 & 46.26 & 15,349 \\
December & 121.93 & 6.57 & 4.13 & 89.56 & 45.86 & 10,778 \\
\hline All Bills & 126.02 & 6.53 & 6.01 & 88.59 & 45.46 & 893,055 \\
\hline \hline
\end{tabular}

Note: The table reports average values calculated using bills from 200801 to 201806 for buildings using heating oil as the main fuel. The first column reports the annual heat energy consumption per square meter of living space. I discard bills that report yearly consumption below $1 \mathrm{kWh} / \mathrm{m}^{2}$. Price of heating fuel is given in euro cents per $\mathrm{kWh}$. Building size is given by the column indicating the number of apartments. Apartment size reports the average size of the apartment in a building in heated living space in square meters. PP per HH is the purchasing power per households at the zip code level (Source: RWI and microm 2020).

Table 8: Response of Heat Energy Consumption to Summer Billing I

Oil Units \& All Building Types

\begin{tabular}{|c|c|c|c|c|c|c|c|c|}
\hline \multirow[t]{2}{*}{ Bill Start } & \multicolumn{8}{|c|}{ Dependent variable: $\ln \left(\mathrm{kWh} / \mathrm{m}^{2}\right)$} \\
\hline & (1) & (2) & (3) & $(4)$ & $(5)$ & (6) & (7) & (8) \\
\hline May & $\begin{array}{l}0.0455^{* * *} \\
(0.006)\end{array}$ & $\begin{array}{l}0.0463^{* * *} \\
(0.005)\end{array}$ & $\begin{array}{l}0.0404^{* * *} \\
(0.005)\end{array}$ & $\begin{array}{l}0.0402^{* * *} \\
(0.005)\end{array}$ & $\begin{array}{l}0.0249^{* * *} \\
(0.005)\end{array}$ & $\begin{array}{l}0.0214^{* * *} \\
(0.005)\end{array}$ & $\begin{array}{l}0.0215^{* * *} \\
(0.005)\end{array}$ & $\begin{array}{l}0.0218^{* * *} \\
(0.005)\end{array}$ \\
\hline June & $\begin{array}{l}0.0476^{* * *} \\
(0.003)\end{array}$ & $\begin{array}{l}0.0475^{* * *} \\
(0.003)\end{array}$ & $\begin{array}{l}0.0389^{* * *} \\
(0.003)\end{array}$ & $\begin{array}{l}0.0388^{* * *} \\
(0.003)\end{array}$ & $\begin{array}{l}0.0441^{* * *} \\
(0.003)\end{array}$ & $\begin{array}{l}0.0400^{* * *} \\
(0.003)\end{array}$ & $\begin{array}{l}0.0386^{* * *} \\
(0.003)\end{array}$ & $\begin{array}{l}0.0356^{* * *} \\
(0.003)\end{array}$ \\
\hline July & $\begin{array}{l}0.0239^{* * *} \\
(0.004)\end{array}$ & $\begin{array}{l}0.0239^{* * *} \\
(0.004)\end{array}$ & $\begin{array}{l}0.0140^{* *} \\
(0.004)\end{array}$ & $\begin{array}{l}0.0139^{* *} \\
(0.004)\end{array}$ & $\begin{array}{l}0.0249^{* * *} \\
(0.004)\end{array}$ & $\begin{array}{l}0.0210^{* * *} \\
(0.004)\end{array}$ & $\begin{array}{l}0.0205^{* * *} \\
(0.005)\end{array}$ & $\begin{array}{l}0.0196^{* * *} \\
(0.005)\end{array}$ \\
\hline Costs per kWh & & $\begin{array}{l}-0.0261^{*} \\
(0.011)\end{array}$ & $\begin{array}{l}-0.0259^{*} \\
(0.011)\end{array}$ & $\begin{array}{c}-0.0259^{*} \\
(0.011)\end{array}$ & $\begin{array}{l}-0.0259^{*} \\
(0.011)\end{array}$ & $\begin{array}{l}-0.0227^{*} \\
(0.009)\end{array}$ & $\begin{array}{l}-0.0225^{*} \\
(0.009)\end{array}$ & $\begin{array}{l}-0.0225^{*} \\
(0.009)\end{array}$ \\
\hline HDD 12 month sum & & & & $\mathrm{Y}$ & $\mathrm{Y}$ & $\mathrm{Y}$ & & $\mathrm{Y}$ \\
\hline Purchasing Power per HH & & & & & & $\mathrm{Y}$ & & \\
\hline Year FE & & & Yes & Yes & Yes & Yes & Yes & Yes \\
\hline \# of Apts FE & Yes & Yes & Yes & Yes & & & & \\
\hline \# of Apts X State FE & & & & & Yes & Yes & & \\
\hline \# of Apts X PLZ FE & & & & & & & Yes & Yes \\
\hline$N$ & 754,868 & 672,735 & 672,735 & 672,735 & 672,686 & 569,047 & 670,234 & 670,234 \\
\hline $\operatorname{Adj} R^{2}$ & 0.010 & 0.017 & 0.042 & 0.042 & 0.082 & 0.083 & 0.316 & 0.323 \\
\hline
\end{tabular}

Note: The omitted month is January (the most common starting month for billing), the control billing cycle. Standard errors clustered at the building level and robust to heteroskedasticity. ${ }^{*} p<0.05,{ }^{* *} p<0.01,{ }^{* * *} p<0.001$. 
Table 9: Response of Heat Energy Consumption to Summer Billing II

Oil Units \& Buildings with up to 10 Apartments

\begin{tabular}{|c|c|c|c|c|c|c|c|c|}
\hline \multirow[t]{2}{*}{ Bill Start } & \multicolumn{8}{|c|}{ Dependent variable: $\ln \left(\mathrm{kWh} / \mathrm{m}^{2}\right)$} \\
\hline & $(1)$ & $(2)$ & (3) & $(4)$ & (5) & (6) & (7) & (8) \\
\hline May & $\begin{array}{l}0.0393^{* * *} \\
(0.006)\end{array}$ & $\begin{array}{l}0.0382^{\text {*** }} \\
(0.005)\end{array}$ & $\begin{array}{l}0.0323^{* * *} \\
(0.005)\end{array}$ & $\begin{array}{l}0.0319^{* * *} \\
(0.005)\end{array}$ & $\begin{array}{l}0.0284^{* * *} \\
(0.005)\end{array}$ & $\begin{array}{l}0.0254^{\text {*** }} \\
(0.005)\end{array}$ & $\begin{array}{l}0.0210^{* * *} \\
(0.006)\end{array}$ & $\begin{array}{l}0.0215^{* * *} \\
(0.006)\end{array}$ \\
\hline June & $\begin{array}{l}0.0504^{* * *} \\
(0.003)\end{array}$ & $\begin{array}{l}0.0502^{* * *} \\
(0.003)\end{array}$ & $\begin{array}{l}0.0418^{* * *} \\
(0.003)\end{array}$ & $\begin{array}{l}0.0416^{* * *} \\
(0.003)\end{array}$ & $\begin{array}{l}0.0474^{* * *} \\
(0.003)\end{array}$ & $\begin{array}{l}0.0433^{* * *} \\
(0.003)\end{array}$ & $\begin{array}{l}0.0388^{* * *} \\
(0.003)\end{array}$ & $\begin{array}{l}0.0360^{* * *} \\
(0.003)\end{array}$ \\
\hline July & $\begin{array}{l}0.0261^{* * *} \\
(0.005)\end{array}$ & $\begin{array}{l}0.0264^{\text {*** }} \\
(0.005)\end{array}$ & $\begin{array}{l}0.0168^{* * *} \\
(0.005)\end{array}$ & $\begin{array}{l}0.0166^{\text {*** }} \\
(0.005)\end{array}$ & $\begin{array}{l}0.0270^{* * *} \\
(0.004)\end{array}$ & $\begin{array}{l}0.0226^{\text {*** }} \\
(0.005)\end{array}$ & $\begin{array}{l}0.0204^{* * *} \\
(0.005)\end{array}$ & $\begin{array}{l}0.0196^{* * *} \\
(0.005)\end{array}$ \\
\hline Costs per kWh & & $\begin{array}{l}-0.0184^{* *} \\
(0.006)\end{array}$ & $\begin{array}{l}-0.0182^{* *} \\
(0.006)\end{array}$ & $\begin{array}{l}-0.0182^{* *} \\
(0.006)\end{array}$ & $\begin{array}{l}-0.0185^{* *} \\
(0.006)\end{array}$ & $\begin{array}{l}-0.0178^{* *} \\
(0.006)\end{array}$ & $\begin{array}{l}-0.0185^{* *} \\
(0.006)\end{array}$ & $\begin{array}{l}-0.0186^{* *} \\
(0.006)\end{array}$ \\
\hline HDD 12 month sum & & & & $\mathrm{Y}$ & $\mathrm{Y}$ & $\mathrm{Y}$ & & $\mathrm{Y}$ \\
\hline Purchasing Power per HH & & & & & & $\mathrm{Y}$ & & \\
\hline Year FE & & & Yes & Yes & Yes & Yes & Yes & Yes \\
\hline \# of Apts FE & Yes & Yes & Yes & Yes & & & & \\
\hline \# of Apts X State FE & & & & & Yes & Yes & & \\
\hline \# of Apts X PLZ FE & & & & & & & Yes & Yes \\
\hline$N$ & 666,376 & 593,135 & 593,135 & 593,135 & 593,135 & 503,095 & 591,765 & 591,765 \\
\hline $\operatorname{Adj} R^{2}$ & 0.009 & 0.013 & 0.040 & 0.040 & 0.070 & 0.071 & 0.277 & 0.284 \\
\hline
\end{tabular}

Note: The omitted month is January (the most common starting month for billing), the control billing cycle. Standard errors clustered at the building level and robust to heteroskedasticity. ${ }^{*} p<0.05,{ }^{* *} p<0.01,{ }^{* * *} p<0.001$.

Table 10: Interaction with Heating Degree Days

Oil Buildings

\begin{tabular}{|c|c|c|c|c|c|c|}
\hline \multirow[t]{2}{*}{ Bill Start } & \multicolumn{6}{|c|}{ Dependent variable: $\ln \left(\mathrm{kWh} / \mathrm{m}^{2}\right)$} \\
\hline & (1) & $(2)$ & $(3)$ & (4) & (5) & (6) \\
\hline May to July & $\begin{array}{l}0.031^{* * *} \\
(0.0062)\end{array}$ & $\begin{array}{l}0.031^{* * *} \\
(0.0090)\end{array}$ & $\begin{array}{l}0.042^{* * *} \\
(0.0116)\end{array}$ & $\begin{array}{l}0.018 \\
(0.0146)\end{array}$ & $\begin{array}{l}0.038^{*} \\
(0.0149)\end{array}$ & $\begin{array}{l}0.040^{* *} \\
(0.0127)\end{array}$ \\
\hline $\mathrm{X}(\mathrm{HDD} / 100)$ 1-month sum & $\begin{array}{l}-0.018^{* * *} \\
(0.0051)\end{array}$ & & & & & \\
\hline $\mathrm{X}(\mathrm{HDD} / 100)$ 2-month sum & & $\begin{array}{l}-0.015^{* * *} \\
(0.0038)\end{array}$ & & & & \\
\hline $\mathrm{X}(\mathrm{HDD} / 100)$ 3-month sum & & & $\begin{array}{l}-0.014^{* * *} \\
(0.0029)\end{array}$ & & & \\
\hline $\mathrm{X}(\mathrm{HDD} / 100)$ 4-month sum & & & & $\begin{array}{l}-0.003 \\
(0.0015)\end{array}$ & & \\
\hline $\mathrm{X}(\mathrm{HDD} / 100)$ 5-month sum & & & & & $\begin{array}{l}-0.001 \\
(0.0010)\end{array}$ & \\
\hline $\mathrm{X}(\mathrm{HDD} / 100) 6$-month sum & & & & & & $\begin{array}{l}-0.001 \\
(0.0009)\end{array}$ \\
\hline$N$ & 670,234 & 670,234 & 670,234 & 670,234 & 670,234 & 670,234 \\
\hline Adj $R^{2}$ & 0.323 & 0.323 & 0.323 & 0.323 & 0.323 & 0.323 \\
\hline
\end{tabular}

Note: The control billing cycle is the calendar year. Each column reports coefficients on the interaction between the pooled treatment group and the annual sum of heating degree days recorded 1 month to 6 months post-billing. In addition to the X-month HDD covariate corresponding to the interaction term, all regressions controlled for heating costs per $\mathrm{kWh}$, 12-month HDD, building size by zip code fixed effects, and year fixed effects. Robust standard errors clustered at the building level. $* p<0.05, * * p<0.01$, $* * * p<0.001$. 
Table 11: Dynamics of Salience

\section{Oil Buildings}

\begin{tabular}{ll}
\hline \hline Bill Start & $\ln \left(\mathrm{kWh} / \mathrm{m}^{2}\right)$ \\
\hline & $(1)$ \\
May to July & -0.006 \\
& $(0.0149)$ \\
\hline $\mathrm{X}(\mathrm{HDD} / 100)$ 1st month & $-0.042^{* * *}$ \\
& $(0.0054)$ \\
$\mathrm{X}(\mathrm{HDD} / 100)$ 2nd month & $-0.033^{* * *}$ \\
& $(0.0072)$ \\
$\mathrm{X}(\mathrm{HDD} / 100)$ 3rd month & $-0.029^{* * *}$ \\
& $(0.0051)$ \\
$\mathrm{X}(\mathrm{HDD} / 100)$ 4th to 6th month & $0.009^{* * *}$ \\
& $(0.0020)$ \\
$\mathrm{X}(\mathrm{HDD} / 100)$ 7th to 12th month & $0.007^{* * *}$ \\
& $(0.0010)$ \\
\hline$N$ & 670,234 \\
Adj $R^{2}$ & 0.324 \\
\hline \hline
\end{tabular}

Note: The control billing cycle is the calendar year. Table reports coefficients on the interaction terms between the pooled treatment group and the heating degree days recorded in the 1st, 2nd, 3rd, 4th to 6th, and 7 th to last month of the billing cycle. In addition to all HDD variables corresponding to the interaction terms, the control set included heating costs per kWh, building size by zip code fixed effects, and year fixed effects. Robust standard errors clustered at the building level. ${ }^{*} p<0.05,{ }^{* *} p<0.01,{ }^{* * *} p<0.001$. 
Table 12: Response of Heat Energy Consumption to Billing Cycles Oil Units - Cost Salience

\begin{tabular}{|c|c|c|c|c|c|}
\hline \multirow[t]{2}{*}{ Bill Start } & \multicolumn{5}{|c|}{ Dependent variable: $\ln \left(\mathrm{kWh} / \mathrm{m}^{2}\right)$} \\
\hline & (1) & $(2)$ & $(3)$ & (4) & $(5)$ \\
\hline & Space & Space & Space & Water & Space Only \\
\hline February & $\begin{array}{l}-0.014 \\
(0.0101)\end{array}$ & $\begin{array}{l}-0.007 \\
(0.0103)\end{array}$ & $\begin{array}{l}-0.005 \\
(0.0115)\end{array}$ & $\begin{array}{l}-0.004 \\
(0.0169)\end{array}$ & $\begin{array}{l}0.013 \\
(0.0232)\end{array}$ \\
\hline March & $\begin{array}{l}-0.011 \\
(0.0093)\end{array}$ & $\begin{array}{l}0.004 \\
(0.0105)\end{array}$ & $\begin{array}{l}0.006 \\
(0.0117)\end{array}$ & $\begin{array}{l}-0.013 \\
(0.0186)\end{array}$ & $\begin{array}{l}0.053^{*} \\
(0.0236)\end{array}$ \\
\hline April & $\begin{array}{l}-0.003 \\
(0.0074)\end{array}$ & $\begin{array}{l}0.020^{*} \\
(0.0102)\end{array}$ & $\begin{array}{l}0.017 \\
(0.0116)\end{array}$ & $\begin{array}{l}-0.038^{*} \\
(0.0176)\end{array}$ & $\begin{array}{l}0.056^{* *} \\
(0.0202)\end{array}$ \\
\hline May & $\begin{array}{l}0.022^{* * *} \\
(0.0054)\end{array}$ & $\begin{array}{l}0.049^{* * *} \\
(0.0099)\end{array}$ & $\begin{array}{l}0.050 * * * \\
(0.0115)\end{array}$ & $\begin{array}{l}-0.035 \\
(0.0184)\end{array}$ & $\begin{array}{l}0.042^{*} \\
(0.0175)\end{array}$ \\
\hline June & $\begin{array}{l}0.037^{* * *} \\
(0.0030)\end{array}$ & $\begin{array}{l}0.066^{* * *} \\
(0.0092)\end{array}$ & $\begin{array}{l}0.073^{* * *} \\
(0.0107)\end{array}$ & $\begin{array}{l}-0.029 \\
(0.0168)\end{array}$ & $\begin{array}{l}0.044^{* *} \\
(0.0158)\end{array}$ \\
\hline July & $\begin{array}{l}0.021^{* * *} \\
(0.0046)\end{array}$ & $\begin{array}{l}0.049^{* * *} \\
(0.0096)\end{array}$ & $\begin{array}{l}0.058^{* * *} \\
(0.0112)\end{array}$ & $\begin{array}{l}-0.064^{* * *} \\
(0.0179)\end{array}$ & $\begin{array}{l}0.027 \\
(0.0170)\end{array}$ \\
\hline August & $\begin{array}{l}0.009 \\
(0.0081)\end{array}$ & $\begin{array}{l}0.033^{* *} \\
(0.0108)\end{array}$ & $\begin{array}{l}0.031^{*} \\
(0.0123)\end{array}$ & $\begin{array}{l}-0.040^{*} \\
(0.0187)\end{array}$ & $\begin{array}{l}0.064^{* *} \\
(0.0245)\end{array}$ \\
\hline September & $\begin{array}{l}0.001 \\
(0.0076)\end{array}$ & $\begin{array}{l}0.018 \\
(0.0091)\end{array}$ & $\begin{array}{l}0.028^{* *} \\
(0.0104)\end{array}$ & $\begin{array}{c}-0.050^{* *} \\
(0.0164)\end{array}$ & $\begin{array}{l}-0.017 \\
(0.0205)\end{array}$ \\
\hline October & $\begin{array}{l}0.003 \\
(0.0062)\end{array}$ & $\begin{array}{l}0.010 \\
(0.0066)\end{array}$ & $\begin{array}{l}0.005 \\
(0.0074)\end{array}$ & $\begin{array}{c}-0.048^{* * *} \\
(0.0116)\end{array}$ & $\begin{array}{l}0.002 \\
(0.0161)\end{array}$ \\
\hline November & $\begin{array}{l}-0.012 \\
(0.0085)\end{array}$ & $\begin{array}{l}-0.012 \\
(0.0085)\end{array}$ & $\begin{array}{l}-0.001 \\
(0.0096)\end{array}$ & $\begin{array}{l}0.004 \\
(0.0156)\end{array}$ & $\begin{array}{l}-0.038 \\
(0.0206)\end{array}$ \\
\hline December & $\begin{array}{l}-0.009 \\
(0.0099)\end{array}$ & $\begin{array}{l}-0.012 \\
(0.0099)\end{array}$ & $\begin{array}{l}-0.021 \\
(0.0112)\end{array}$ & $\begin{array}{l}-0.013 \\
(0.0181)\end{array}$ & $\begin{array}{l}0.006 \\
(0.0266)\end{array}$ \\
\hline Costs per kWh - Space & $\begin{array}{c}-0.022^{* *} \\
(0.0086)\end{array}$ & $\begin{array}{c}-0.022^{* *} \\
(0.0086)\end{array}$ & $\begin{array}{c}-0.064^{* *} \\
(0.0219)\end{array}$ & & $\begin{array}{c}-0.020^{* *} \\
(0.0075)\end{array}$ \\
\hline Costs per kWh - Water & & & & $\begin{array}{c}-0.017^{* *} \\
(0.0062)\end{array}$ & \\
\hline HDD 12 month sum & $\mathrm{Y}$ & $\mathrm{Y}$ & $\mathrm{Y}$ & $\mathrm{Y}$ & $\mathrm{Y}$ \\
\hline HDD 3 month sum & & $\mathrm{Y}$ & $\mathrm{Y}$ & $\mathrm{Y}$ & $\mathrm{Y}$ \\
\hline Year FE & Yes & Yes & Yes & Yes & Yes \\
\hline \# of Apts x PLZ FE & Yes & Yes & Yes & Yes & Yes \\
\hline$N$ & 794,666 & 794,666 & 584,069 & 586,631 & 209,543 \\
\hline $\operatorname{Adj} R^{2}$ & 0.302 & 0.302 & 0.299 & 0.290 & 0.447 \\
\hline
\end{tabular}

Note: The omitted month is January (the most common starting month for billing), the control month group. Standard errors clustered at the building level and robust to heteroskedasticity. ${ }^{*} p<0.05,{ }^{* *} p<0.01,{ }^{* * *} p<0.001$. 
Table 13: Descriptives by Terciles of the Unemployment Rate

Oil Units in 2009

\begin{tabular}{lcccc}
\hline \hline Quantile & T1 & T2 & T3 & Full Sample \\
\hline Unemployment \% & 2.72 & 5.03 & 9.94 & 5.55 \\
Purchasing Power per HH & 45.80 & 42.12 & 35.98 & 41.74 \\
Annual kWh $/ \mathrm{m}^{2}$ & 128.35 & 136.82 & 144.85 & 136.10 \\
Costs per kWh & 0.061 & 0.061 & 0.061 & 0.061 \\
No. of Apartments & 4.86 & 5.16 & 8.15 & 5.85 \\
East Dummy & 0.01 & 0.01 & 0.23 & 0.07 \\
Calendar Year & 0.39 & 0.45 & 0.51 & 0.45 \\
May to July & 0.39 & 0.38 & 0.36 & 0.38 \\
\hline Zip Codes & 2,452 & 2,467 & 2,195 & 6,865 \\
No. of Buildings & 27,820 & 33,335 & 21,866 & 83,246 \\
\hline \hline
\end{tabular}

Note: The table reports average values using the all building types in year 2009. Unemployment rate and purchasing power per household are computed at the zipcode level using data from RWI and microm (2019). Price of heating fuel is given in euro per kWh. East dummy indicates the share of buildings located in the following federal states: Berlin, Brandenburg, Mecklenburg-Vorpommern, Freistaat Sachsen, Sachsen-Anhalt, and Freistaat Thüringen. Calendar year reports the share of buildings that were treated with the January to December billing cycle. May to July reports the proportion of buildings that billing cycles starting in those months. 
Table 14: Estimates of the Conditional Average Treatment Effects

Oil Units By Terciles of Unemployment Rate

\begin{tabular}{|c|c|c|c|c|}
\hline \multirow[t]{2}{*}{ Bill Start } & \multicolumn{4}{|c|}{ Dependent variable: $\ln \left(\mathrm{kWh} / \mathrm{m}^{2}\right)$} \\
\hline & $\mathrm{T} 1$ & $\mathrm{~T} 2$ & $\mathrm{~T} 3$ & Full \\
\hline April to August & $\begin{array}{l}0.0055 \\
(0.011)\end{array}$ & $\begin{array}{l}0.0273^{*} \\
(0.011)\end{array}$ & $\begin{array}{l}0.0470^{* * *} \\
(0.014)\end{array}$ & $\begin{array}{l}0.0225^{* *} \\
(0.007)\end{array}$ \\
\hline & $\mathrm{T} 1$ & $\mathrm{~T} 2$ & $\mathrm{~T} 3$ & Full \\
\hline February & $\begin{array}{c}-0.0249 \\
(0.017)\end{array}$ & $\begin{array}{l}0.0029 \\
(0.017)\end{array}$ & $\begin{array}{l}0.0076 \\
(0.022)\end{array}$ & $\begin{array}{c}-0.0084 \\
(0.011)\end{array}$ \\
\hline March & $\begin{array}{c}-0.0097 \\
(0.018)\end{array}$ & $\begin{array}{l}0.0060 \\
(0.017)\end{array}$ & $\begin{array}{l}0.0148 \\
(0.023)\end{array}$ & $\begin{array}{l}0.0018 \\
(0.011)\end{array}$ \\
\hline April & $\begin{array}{c}-0.0057 \\
(0.018)\end{array}$ & $\begin{array}{l}0.0223 \\
(0.017)\end{array}$ & $\begin{array}{l}0.0457^{*} \\
(0.021)\end{array}$ & $\begin{array}{l}0.0158 \\
(0.011)\end{array}$ \\
\hline May & $\begin{array}{l}0.0227 \\
(0.018)\end{array}$ & $\begin{array}{l}0.0476^{* *} \\
(0.017)\end{array}$ & $\begin{array}{l}0.0680^{* * *} \\
(0.020)\end{array}$ & $\begin{array}{l}0.0430^{* * *} \\
(0.011)\end{array}$ \\
\hline June & $\begin{array}{l}0.0497^{* *} \\
(0.017)\end{array}$ & $\begin{array}{l}0.0668^{* * *} \\
(0.016)\end{array}$ & $\begin{array}{l}0.0657^{* * *} \\
(0.019)\end{array}$ & $\begin{array}{l}0.0595^{* * *} \\
(0.010)\end{array}$ \\
\hline July & $\begin{array}{l}0.0290 \\
(0.018)\end{array}$ & $\begin{array}{l}0.0605^{* * *} \\
(0.017)\end{array}$ & $\begin{array}{l}0.0379 \\
(0.020)\end{array}$ & $\begin{array}{l}0.0439^{* * *} \\
(0.011)\end{array}$ \\
\hline August & $\begin{array}{l}0.0052 \\
(0.018)\end{array}$ & $\begin{array}{l}0.0339 \\
(0.018)\end{array}$ & $\begin{array}{l}0.0695^{* *} \\
(0.024)\end{array}$ & $\begin{array}{l}0.0272 * \\
(0.012)\end{array}$ \\
\hline September & $\begin{array}{l}0.0264 \\
(0.015)\end{array}$ & $\begin{array}{l}0.0034 \\
(0.015)\end{array}$ & $\begin{array}{l}0.0086 \\
(0.021)\end{array}$ & $\begin{array}{l}0.0153 \\
(0.010)\end{array}$ \\
\hline October & $\begin{array}{c}-0.0065 \\
(0.011)\end{array}$ & $\begin{array}{l}0.0264^{*} \\
(0.011)\end{array}$ & $\begin{array}{l}0.0066 \\
(0.014)\end{array}$ & $\begin{array}{l}0.0092 \\
(0.007)\end{array}$ \\
\hline November & $\begin{array}{c}-0.0094 \\
(0.013)\end{array}$ & $\begin{array}{c}-0.0033 \\
(0.013)\end{array}$ & $\begin{array}{c}-0.0229 \\
(0.018)\end{array}$ & $\begin{array}{c}-0.0095 \\
(0.009)\end{array}$ \\
\hline December & $\begin{array}{c}-0.0288 \\
(0.016)\end{array}$ & $\begin{array}{l}-0.0076 \\
(0.015)\end{array}$ & $\begin{array}{l}0.0319 \\
(0.019)\end{array}$ & $\begin{array}{c}-0.0086 \\
(0.010)\end{array}$ \\
\hline Costs per kWh & $\begin{array}{l}-0.0118^{* * *} \\
(0.002)\end{array}$ & $\begin{array}{l}-0.0310^{* * *} \\
(0.004)\end{array}$ & $\begin{array}{l}-0.0582^{* * *} \\
(0.011)\end{array}$ & $\begin{array}{l}-0.0198^{* *} \\
(0.007)\end{array}$ \\
\hline HDD 12 month sum & $\mathrm{Y}$ & $\mathrm{Y}$ & $\mathrm{Y}$ & $\mathrm{Y}$ \\
\hline HDD 3 month sum & $\mathrm{Y}$ & $\mathrm{Y}$ & $\mathrm{Y}$ & $\mathrm{Y}$ \\
\hline Year FE & Yes & Yes & Yes & Yes \\
\hline \# of Apts x PLZ FE & Yes & Yes & Yes & Yes \\
\hline$N$ & 228,296 & 264,933 & 182,392 & 677,700 \\
\hline $\operatorname{Adj} R^{2}$ & 0.281 & 0.268 & 0.359 & 0.304 \\
\hline
\end{tabular}

Note: Data on the unemployment rate was available from 2009 to 2017 . The full sample in the last column covers all terciles for 2009 to 2017. The first row reports CATE when treatment group consists of non-heating months April to August and control group consists of September to March. For April to August, the pooled treatment group, the differences between the coefficients by terciles are not statistically significant in a regression with interactions between treatment and terciles. Using separate regressions, the rows below report estimates for each billing period, where the omitted month is January, the control month group. Standard errors clustered at the building level and robust to heteroskedasticity for all regressions. ${ }^{*} p<0.05,{ }^{* *} p<0.01,{ }^{* * *} p<0.001$. 
Table 15: Heating vs. Non-Heating Months

Oil Buildings

\begin{tabular}{|c|c|c|c|c|}
\hline \multirow[t]{2}{*}{ Bill Start } & \multicolumn{4}{|c|}{ Dependent variable: $\ln \left(\mathrm{kWh} / \mathrm{m}^{2}\right)$} \\
\hline & (1) & $(2)$ & (3) & $(4)$ \\
\hline May to July & $\begin{array}{l}0.0414^{* * *} \\
(0.00486)\end{array}$ & $\begin{array}{l}0.0416^{* * *} \\
(0.00488)\end{array}$ & & \\
\hline April to August & & & $\begin{array}{l}0.0368 * * * \\
(0.00468)\end{array}$ & $\begin{array}{l}0.0369 * * * \\
(0.00469)\end{array}$ \\
\hline Costs per kWh & $\begin{array}{l}-0.0381^{* * *} \\
(0.00627)\end{array}$ & $\begin{array}{l}-0.0361^{* * *} \\
(0.00551)\end{array}$ & $\begin{array}{l}-0.0378^{* * *} \\
(0.00616)\end{array}$ & $\begin{array}{l}-0.0358^{* * *} \\
(0.00541)\end{array}$ \\
\hline HDD 12 month sum & $\mathrm{Y}$ & $\mathrm{Y}$ & $\mathrm{Y}$ & $\mathrm{Y}$ \\
\hline Year FE & Yes & Yes & Yes & Yes \\
\hline \# of Apts X PLZ FE & Yes & Yes & Yes & Yes \\
\hline Sample & All & Apts $<11$ & All & Apts $<11$ \\
\hline$N$ & 326,338 & 309,930 & 362,210 & 344,790 \\
\hline $\operatorname{Adj} R^{2}$ & 0.351 & 0.331 & 0.338 & 0.318 \\
\hline
\end{tabular}

Note: The full sample now excludes the calendar year billing period. The control or omitted group consists of buildings billed starting in September to December, February, and March. In the first two columns, I further exclude April and August from the sample. Robust standard errors clustered at the zip code level. ${ }^{*} p<0.05,{ }^{* *} p<0.01,{ }^{* * *} p<0.001$.

Table 16: Year of Construction

Oil Buildings

\begin{tabular}{lcccccc}
\hline \hline & & & \multicolumn{5}{c}{ Building Code Regulation } \\
\cline { 4 - 7 } Bill Start & Pre-1919 & $1919-1977$ & $1978-1983$ & $1984-1994$ & $1995-2001$ & $2002+$ \\
\hline \multirow{2}{*}{ Jan } & 1892 & 1964 & 1980 & 1990 & 1997 & 2004 \\
Feb & 1878 & 1961 & 1980 & 1991 & 1997 & 2005 \\
Mar & 1902 & 1962 & 1980 & 1991 & 1997 & 2003 \\
Apr & 1893 & 1962 & 1980 & 1990 & 1997 & 2005 \\
May & 1893 & 1962 & 1980 & 1990 & 1996 & 2004 \\
June & 1888 & 1965 & 1980 & 1989 & 1997 & 2003 \\
July & 1887 & 1963 & 1981 & 1989 & 1997 & 2004 \\
Aug & 1885 & 1964 & 1980 & 1990 & 1997 & 2003 \\
Sept & 1878 & 1961 & 1980 & 1990 & 1997 & 2003 \\
Oct & 1885 & 1961 & 1981 & 1990 & 1997 & 2004 \\
Nov & 1887 & 1964 & 1980 & 1990 & 1997 & 2003 \\
Dec & 1892 & 1962 & 1981 & 1990 & 1997 & 2003 \\
\hline All Bills & 1891 & 1964 & 1980 & 1990 & 1997 & 2004 \\
\# of Buildings & 3,257 & 25,074 & 4,014 & 6,328 & 2,679 & 297 \\
\hline \hline
\end{tabular}

Note: The table reports average values calculated using information reported on energy performance certificates, observed from 2008 to 2018 for buildings using heating oil as the main fuel. 
Table 17: Oil Units with Energy Performance Certificates

Calendar Year Versus Other Billing Cycles

\begin{tabular}{|c|c|c|c|c|c|}
\hline \multirow[t]{2}{*}{ Bill Start } & \multicolumn{4}{|c|}{ Dependent variable: $\ln \left(\mathrm{kWh} / \mathrm{m}^{2}\right)$} & \multirow[b]{2}{*}{$(5)$} \\
\hline & (1) & $(2)$ & $(3)$ & (4) & \\
\hline February & $\begin{array}{l}-0.025 \\
(0.0205)\end{array}$ & $\begin{array}{l}-0.036 \\
(0.0198)\end{array}$ & $\begin{array}{l}-0.037 \\
(0.0197)\end{array}$ & $\begin{array}{l}-0.026 \\
(0.0146)\end{array}$ & $\begin{array}{l}-0.049^{*} \\
(0.0244)\end{array}$ \\
\hline March & $\begin{array}{l}0.054^{* *} \\
(0.0199)\end{array}$ & $\begin{array}{l}0.054^{* *} \\
(0.0190)\end{array}$ & $\begin{array}{l}0.052^{* *} \\
(0.0190)\end{array}$ & $\begin{array}{l}0.045^{* *} \\
(0.0151)\end{array}$ & $\begin{array}{l}0.059^{*} \\
(0.0257)\end{array}$ \\
\hline April & $\begin{array}{l}0.014 \\
(0.0165)\end{array}$ & $\begin{array}{l}0.010 \\
(0.0160)\end{array}$ & $\begin{array}{l}0.009 \\
(0.0160)\end{array}$ & $\begin{array}{l}0.024 \\
(0.0128)\end{array}$ & $\begin{array}{l}0.007 \\
(0.0206)\end{array}$ \\
\hline May & $\begin{array}{l}0.057 * * * \\
(0.0149)\end{array}$ & $\begin{array}{l}0.047^{* *} \\
(0.0146)\end{array}$ & $\begin{array}{l}0.046^{* *} \\
(0.0146)\end{array}$ & $\begin{array}{l}0.054^{* * *} \\
(0.0120)\end{array}$ & $\begin{array}{l}0.051^{* *} \\
(0.0186)\end{array}$ \\
\hline June & $\begin{array}{l}0.063^{* * *} \\
(0.0129)\end{array}$ & $\begin{array}{l}0.046^{* * *} \\
(0.0127)\end{array}$ & $\begin{array}{l}0.047^{* * *} \\
(0.0127)\end{array}$ & $\begin{array}{l}0.048^{* * *} \\
(0.0108)\end{array}$ & $\begin{array}{l}0.047^{* *} \\
(0.0169)\end{array}$ \\
\hline July & $\begin{array}{l}0.045^{* *} \\
(0.0138)\end{array}$ & $\begin{array}{l}0.043^{* *} \\
(0.0136)\end{array}$ & $\begin{array}{l}0.043^{* *} \\
(0.0136)\end{array}$ & $\begin{array}{l}0.039^{* * *} \\
(0.0114)\end{array}$ & $\begin{array}{l}0.057^{* *} \\
(0.0186)\end{array}$ \\
\hline August & $\begin{array}{l}0.054^{* *} \\
(0.0168)\end{array}$ & $\begin{array}{l}0.046^{* *} \\
(0.0166)\end{array}$ & $\begin{array}{l}0.046^{* *} \\
(0.0165)\end{array}$ & $\begin{array}{l}0.034^{* *} \\
(0.0132)\end{array}$ & $\begin{array}{l}0.063^{*} \\
(0.0260)\end{array}$ \\
\hline September & $\begin{array}{l}0.006 \\
(0.0152)\end{array}$ & $\begin{array}{l}-0.001 \\
(0.0149)\end{array}$ & $\begin{array}{l}-0.001 \\
(0.0148)\end{array}$ & $\begin{array}{l}0.020 \\
(0.0121)\end{array}$ & $\begin{array}{l}0.008 \\
(0.0231)\end{array}$ \\
\hline October & $\begin{array}{l}-0.007 \\
(0.0119)\end{array}$ & $\begin{array}{l}-0.009 \\
(0.0115)\end{array}$ & $\begin{array}{l}-0.010 \\
(0.0115)\end{array}$ & $\begin{array}{l}0.005 \\
(0.0090)\end{array}$ & $\begin{array}{l}0.002 \\
(0.0162)\end{array}$ \\
\hline November & $\begin{array}{l}0.004 \\
(0.0166)\end{array}$ & $\begin{array}{l}-0.005 \\
(0.0158)\end{array}$ & $\begin{array}{l}-0.004 \\
(0.0159)\end{array}$ & $\begin{array}{l}0.008 \\
(0.0134)\end{array}$ & $\begin{array}{l}-0.006 \\
(0.0266)\end{array}$ \\
\hline December & $\begin{array}{c}-0.067^{* * *} \\
(0.0198)\end{array}$ & $\begin{array}{l}-0.071^{* * *} \\
(0.0186)\end{array}$ & $\begin{array}{l}-0.072^{* * *} \\
(0.0186)\end{array}$ & $\begin{array}{c}-0.048^{* *} \\
(0.0149)\end{array}$ & $\begin{array}{l}-0.055^{*} \\
(0.0262)\end{array}$ \\
\hline Costs per kWh & $\begin{array}{l}-0.038 * * * \\
(0.0082)\end{array}$ & $\begin{array}{c}-0.038 * * * \\
(0.0083)\end{array}$ & $\begin{array}{c}-0.038^{* * *} \\
(0.0083)\end{array}$ & $\begin{array}{c}-0.039^{* * *} \\
(0.0082)\end{array}$ & $\begin{array}{l}-0.032^{* * *} \\
(0.0038)\end{array}$ \\
\hline Year of Construction & & & $\begin{array}{l}-0.0004^{* * *} \\
(0.0001)\end{array}$ & & \\
\hline Minimum EPC score & & & & $\begin{array}{l}0.005^{* * *} \\
(0.0001)\end{array}$ & \\
\hline 2008 EPC score & & & & & $\begin{array}{l}0.004^{* * *} \\
(0.0001)\end{array}$ \\
\hline HDD 12 month sum & $\mathrm{Y}$ & $\mathrm{Y}$ & $\mathrm{Y}$ & $\mathrm{Y}$ & $\mathrm{Y}$ \\
\hline HDD 3 month sum & $\mathrm{Y}$ & $\mathrm{Y}$ & $\mathrm{Y}$ & $\mathrm{Y}$ & $\mathrm{Y}$ \\
\hline Year FE & Yes & Yes & Yes & Yes & Yes \\
\hline \# of Apts X PLZ FE & Yes & Yes & Yes & Yes & Yes \\
\hline Building Code FE & & Yes & Yes & Yes & Yes \\
\hline$N$ & 315,298 & 315,298 & 315,298 & 315,298 & 129,703 \\
\hline Adj $R^{2}$ & 0.442 & 0.457 & 0.457 & 0.539 & 0.548 \\
\hline
\end{tabular}

Note: The control or omitted group consists of buildings with calendar year billing. Robust standard errors clustered at the building level. ${ }^{*} p<0.05,{ }^{* *} p<0.01,{ }^{* * *} p<0.001$. 
Table 18: Oil Units Constructed Before 1978

Calendar Year Versus Other Billing Cycles

\begin{tabular}{|c|c|c|c|c|c|}
\hline \multirow[t]{3}{*}{ Bill Start } & \multicolumn{4}{|c|}{ Dependent variable: $\ln \left(\mathrm{kWh} / \mathrm{m}^{2}\right)$} & \multirow[b]{2}{*}{$(5)$} \\
\hline & $(1)$ & $(2)$ & $(3)$ & $(4)$ & \\
\hline & All Types & $2 \mathrm{HH}$ & $3-6 \mathrm{HH}$ & $7-12 \mathrm{HH}$ & $13+\mathrm{HH}$ \\
\hline February & $\begin{array}{l}-0.034 \\
(0.0232)\end{array}$ & $\begin{array}{l}0.041 \\
(0.0436)\end{array}$ & $\begin{array}{l}-0.047 \\
(0.0293)\end{array}$ & $\begin{array}{l}-0.060 \\
(0.0792)\end{array}$ & $\begin{array}{l}-0.330 * * * \\
(0.0550)\end{array}$ \\
\hline March & $\begin{array}{l}0.056^{*} \\
(0.0245)\end{array}$ & $\begin{array}{l}0.134^{* *} \\
(0.0473)\end{array}$ & $\begin{array}{l}0.066^{*} \\
(0.0314)\end{array}$ & $\begin{array}{l}-0.133 \\
(0.0872)\end{array}$ & $\begin{array}{l}-0.056 \\
(0.1246)\end{array}$ \\
\hline April & $\begin{array}{l}0.032 \\
(0.0195)\end{array}$ & $\begin{array}{l}0.093 \\
(0.0485)\end{array}$ & $\begin{array}{l}0.036 \\
(0.0247)\end{array}$ & $\begin{array}{l}0.002 \\
(0.0516)\end{array}$ & $\begin{array}{l}0.102 \\
(0.0774)\end{array}$ \\
\hline May & $\begin{array}{l}0.065^{* * *} \\
(0.0171)\end{array}$ & $\begin{array}{l}0.125^{* *} \\
(0.0452)\end{array}$ & $\begin{array}{l}0.066^{* *} \\
(0.0232)\end{array}$ & $\begin{array}{l}0.088^{*} \\
(0.0399)\end{array}$ & $\begin{array}{l}-0.008 \\
(0.0508)\end{array}$ \\
\hline June & $\begin{array}{l}0.051^{* * *} \\
(0.0149)\end{array}$ & $\begin{array}{l}0.153^{* * *} \\
(0.0435)\end{array}$ & $\begin{array}{l}0.049^{*} \\
(0.0207)\end{array}$ & $\begin{array}{l}0.043 \\
(0.0316)\end{array}$ & $\begin{array}{l}0.035 \\
(0.0444)\end{array}$ \\
\hline July & $\begin{array}{l}0.044^{* *} \\
(0.0165)\end{array}$ & $\begin{array}{l}0.114^{* *} \\
(0.0441)\end{array}$ & $\begin{array}{l}0.051^{*} \\
(0.0223)\end{array}$ & $\begin{array}{l}0.043 \\
(0.0382)\end{array}$ & $\begin{array}{l}-0.089 \\
(0.0675)\end{array}$ \\
\hline August & $\begin{array}{l}0.059^{* *} \\
(0.0208)\end{array}$ & $\begin{array}{l}0.125^{*} \\
(0.0507)\end{array}$ & $\begin{array}{l}0.060^{*} \\
(0.0263)\end{array}$ & $\begin{array}{l}0.071 \\
(0.0408)\end{array}$ & $\begin{array}{l}-0.062 \\
(0.0902)\end{array}$ \\
\hline September & $\begin{array}{l}-0.018 \\
(0.0196)\end{array}$ & $\begin{array}{l}0.090^{*} \\
(0.0439)\end{array}$ & $\begin{array}{l}-0.038 \\
(0.0246)\end{array}$ & $\begin{array}{l}-0.015 \\
(0.0435)\end{array}$ & $\begin{array}{l}-0.034 \\
(0.1020)\end{array}$ \\
\hline October & $\begin{array}{l}-0.009 \\
(0.0159)\end{array}$ & $\begin{array}{l}0.027 \\
(0.0303)\end{array}$ & $\begin{array}{l}-0.001 \\
(0.0204)\end{array}$ & $\begin{array}{l}-0.035 \\
(0.0403)\end{array}$ & $\begin{array}{l}-0.225 \\
(0.1498)\end{array}$ \\
\hline November & $\begin{array}{l}-0.006 \\
(0.0221)\end{array}$ & $\begin{array}{l}-0.086 \\
(0.0602)\end{array}$ & $\begin{array}{l}0.027 \\
(0.0270)\end{array}$ & $\begin{array}{l}-0.006 \\
(0.0408)\end{array}$ & $\begin{array}{c}-0.162^{* *} \\
(0.0543)\end{array}$ \\
\hline December & $\begin{array}{c}-0.063^{* *} \\
(0.0236)\end{array}$ & $\begin{array}{c}-0.118^{*} \\
(0.0496)\end{array}$ & $\begin{array}{l}-0.049 \\
(0.0326)\end{array}$ & $\begin{array}{l}-0.035 \\
(0.0435)\end{array}$ & $\begin{array}{l}-0.035 \\
(0.0452)\end{array}$ \\
\hline Costs per kWh & $\begin{array}{l}-0.039^{* * *} \\
(0.0085)\end{array}$ & $\begin{array}{l}-0.042^{* * *} \\
(0.0004)\end{array}$ & $\begin{array}{l}-0.027^{* * *} \\
(0.0007)\end{array}$ & $\begin{array}{l}-0.092^{* * *} \\
(0.0056)\end{array}$ & $\begin{array}{l}-0.100^{* * *} \\
(0.0035)\end{array}$ \\
\hline HDD 12 month sum & $\mathrm{Y}$ & $\mathrm{Y}$ & $\mathrm{Y}$ & $\mathrm{Y}$ & $\mathrm{Y}$ \\
\hline HDD 3 month sum & $\mathrm{Y}$ & $\mathrm{Y}$ & $\mathrm{Y}$ & $\mathrm{Y}$ & $\mathrm{Y}$ \\
\hline Year FE & Yes & Yes & Yes & Yes & Yes \\
\hline \# of Apts X PLZ FE & Yes & Yes & Yes & Yes & Yes \\
\hline$N$ & 209,141 & 25,717 & 110,145 & 41,293 & 31,986 \\
\hline $\operatorname{Adj} R^{2}$ & 0.468 & 0.402 & 0.397 & 0.538 & 0.654 \\
\hline
\end{tabular}

Note: The control or omitted group consists of buildings with calendar year billing.

Robust standard errors clustered at the building level. ${ }^{*} p<0.05,{ }^{* *} p<0.01,{ }^{* * *} p<0.001$. 
Table 19: Stuttgart and Munich

Oil Buildings

\begin{tabular}{lllll}
\hline \hline Bill Start & \multicolumn{3}{c}{$\ln \left(\mathrm{kWh} / \mathrm{m}^{2}\right)$} \\
\hline & \multicolumn{3}{c}{$\begin{array}{c}\text { Stuttgart } \\
\text { ROR 810) }\end{array}$} & \multicolumn{2}{c}{$\begin{array}{c}\text { Munich } \\
\text { ROR 910) }\end{array}$} \\
May to July & $\begin{array}{l}0.0574^{* * *} \\
(0.0111)\end{array}$ & $\begin{array}{l}0.0529^{* * *}(0.0119) \\
0.0577^{* * *}\end{array}$ & $\begin{array}{l}0.0581^{* * *} \\
(0.0166)\end{array}$ & $(0.0173)$ \\
\hline HDD 12 month sum & Y & Y & Y & Y \\
\hline Year FE & Yes & Yes & Yes & Yes \\
\# of Apts X PLZ FE & Yes & Yes & Yes & Yes \\
Sample & All & Apts $<7$ & All & Apts $<7$ \\
\hline$N$ & 36,157 & 27,933 & 32,597 & 25,480 \\
Adj $R^{2}$ & 0.224 & 0.180 & 0.267 & 0.218 \\
\hline \hline
\end{tabular}

Note: The control group consists of other billing cycles. The results are not sensitive to the exclusion of heating costs per $\mathrm{kWh}$ as a control variable. ROR stands for "Raumordnungsregion" or regional planning region. Robust standard errors clustered at the building level. ${ }^{*} p<0.05,{ }^{* *} p<0.01,{ }^{* * *} p<0.001$.

Table 20: Sample Means - Oil Buildings Built Pre-1978

\begin{tabular}{|c|c|c|c|c|c|c|c|}
\hline \multicolumn{8}{|c|}{ Panel A: Year of Construction/Renovation } \\
\hline & Year Built & Heater & Roof & Loft & Outer Wall & Windows & Basement \\
\hline $\begin{array}{c}\text { Calendar Year } \\
\text { (SD) }\end{array}$ & $\begin{array}{l}1955.81 \\
(29.35)\end{array}$ & $\begin{array}{l}1996.12 \\
(12.09)\end{array}$ & $\begin{array}{l}1974.94 \\
(26.94)\end{array}$ & $\begin{array}{l}1968.35 \\
(27.53)\end{array}$ & $\begin{array}{l}1965.63 \\
(27.51)\end{array}$ & $\begin{array}{l}1976.99 \\
(25.41)\end{array}$ & $\begin{array}{l}1960.84 \\
(26.46)\end{array}$ \\
\hline $\mathrm{N}$ & 14,164 & 12,451 & 5,163 & 7,473 & 8,360 & 6,303 & 9,373 \\
\hline $\begin{array}{c}\text { May to July } \\
\text { (SD) } \\
\text { N }\end{array}$ & $\begin{array}{l}1956.33 \\
(30.99) \\
10,554\end{array}$ & $\begin{array}{l}1995.49 \\
(12.50) \\
8,878\end{array}$ & $\begin{array}{l}1979.76 \\
(26.90) \\
3,257\end{array}$ & $\begin{array}{l}1969.50 \\
(28.13) \\
5,089\end{array}$ & $\begin{array}{l}1966.16 \\
(29.02) \\
5,850\end{array}$ & $\begin{array}{l}1982.91 \\
(29.66) \\
4,081\end{array}$ & $\begin{array}{l}1960.61 \\
(27.62) \\
6,738\end{array}$ \\
\hline \multicolumn{8}{|c|}{ Panel B: WSVO 1995 (=1 if meets standards) } \\
\hline & Overall & Heater & Roof & Loft & Outer Wall & Windows & Basement \\
\hline $\begin{array}{c}\text { Calendar Year } \\
\text { (SD) } \\
\text { N }\end{array}$ & $\begin{array}{l}1.299 \\
(1.506) \\
5,741\end{array}$ & $\begin{array}{l}0.611 \\
(0.488) \\
12,451\end{array}$ & $\begin{array}{l}0.326 \\
(0.469) \\
5,741\end{array}$ & $\begin{array}{l}0.343 \\
(0.475) \\
5,741\end{array}$ & $\begin{array}{l}0.196 \\
(0.397) \\
5,741\end{array}$ & $\begin{array}{l}0.360 \\
(0.480) \\
5,741\end{array}$ & $\begin{array}{l}0.074 \\
(0.262) \\
5,741\end{array}$ \\
\hline $\begin{array}{c}\text { May to July } \\
\text { (SD) } \\
\text { N }\end{array}$ & $\begin{array}{l}1.705 \\
(1.471) \\
3.584\end{array}$ & $\begin{array}{l}0.599 \\
(0.490) \\
8,878\end{array}$ & $\begin{array}{l}0.425 \\
(0.494) \\
3.584\end{array}$ & $\begin{array}{l}0.438 \\
(0.496) \\
3.584\end{array}$ & $\begin{array}{l}0.239 \\
(0.427) \\
3,584\end{array}$ & $\begin{array}{l}0.522 \\
(0.500) \\
3.584\end{array}$ & $\begin{array}{l}0.081 \\
(0.272) \\
3.584\end{array}$ \\
\hline
\end{tabular}

Note: Standard deviations in parentheses. "Overall" indicates the number of building components (roof, loft ceiling, windows, outer wall, and basement ceiling) that meet thermal efficiency standards under WSVO 1995 building codes. This information was only available from energy performance certificates issued from 2014 to 2019. 
Table 21: Differences in Energy Efficiency Investments

Oil Buildings Built Before 1978

\begin{tabular}{llllllll}
\hline \hline Bill Start & \multicolumn{7}{c}{ Dependent variable: WSVO 1995 Standard } \\
\hline \multirow{2}{*}{ May to July } & Overall & Heater & Roof & Loft & Outer Wall & Windows & Basement \\
& $\begin{array}{l}0.231^{* * *} \\
(0.0435)\end{array}$ & $\begin{array}{l}-0.00262 \\
(0.0123)\end{array}$ & $\begin{array}{l}0.0596^{* * *} \\
(0.0151)\end{array}$ & $\begin{array}{l}0.0192 \\
(0.0120)\end{array}$ & $\begin{array}{l}0.0546^{* * *} \\
(0.0150)\end{array}$ & $\begin{array}{l}0.0917^{* * *} \\
(0.0144)\end{array}$ & $\begin{array}{l}0.00560 \\
(0.00789)\end{array}$ \\
\hline Year Built & -0.0010 & -0.0001 & $-0.0007^{*}$ & 0.0001 & $-0.0006^{*}$ & 0.0004 & -0.0001 \\
& $(0.0009)$ & $(0.0002)$ & $(0.0003)$ & $(0.0003)$ & $(0.0003)$ & $(0.0003)$ & $(0.0002)$ \\
\hline Year of EPC FE & Yes & Yes & Yes & Yes & Yes & Yes & Yes \\
\# of Apts FE & Yes & Yes & Yes & Yes & Yes & Yes & Yes \\
PLZ FE & Yes & Yes & Yes & Yes & Yes & Yes & Yes \\
\hline$N$ & 7,968 & 9,183 & 7,968 & 7,968 & 7,968 & 7,968 & 7,968 \\
Adj $R^{2}$ & 0.189 & 0.070 & 0.135 & 0.099 & 0.124 & 0.173 & 0.079 \\
\hline \hline
\end{tabular}

Note: The omitted billing month is January (calendar year billing), the control group. Standard errors clustered at the zip code level. Data is limited to energy performance certificates issued 2014 to 2019. Inclusion of controls such as heating costs (total bill) and total living space does not change the results in the table. ${ }^{*} p<0.05,{ }^{* *} p<0.01,{ }^{* * *} p<0.001$ 
Table 22: Natural Gas Building with Energy Performance Certificate Calendar Year Versus Other Billing Cycles

\begin{tabular}{|c|c|c|c|c|c|}
\hline \multirow[t]{2}{*}{ Bill Start } & \multicolumn{4}{|c|}{ Dependent variable: $\ln \left(\mathrm{kWh} / \mathrm{m}^{2}\right)$} & \multirow[b]{2}{*}{$(5)$} \\
\hline & (1) & $(2)$ & $(3)$ & $(4)$ & \\
\hline February & $\begin{array}{l}0.077^{* * *} \\
(0.0076)\end{array}$ & $\begin{array}{l}0.061^{* * *} \\
(0.0125)\end{array}$ & $\begin{array}{l}0.019 \\
(0.0112)\end{array}$ & $\begin{array}{l}0.019 \\
(0.0112)\end{array}$ & $\begin{array}{l}0.012 \\
(0.0089)\end{array}$ \\
\hline March & $\begin{array}{l}0.078^{* * *} \\
(0.0080)\end{array}$ & $\begin{array}{l}0.055^{* * *} \\
(0.0131)\end{array}$ & $\begin{array}{l}0.021 \\
(0.0117)\end{array}$ & $\begin{array}{l}0.021 \\
(0.0117)\end{array}$ & $\begin{array}{l}0.009 \\
(0.0094)\end{array}$ \\
\hline April & $\begin{array}{l}0.079^{* * *} \\
(0.0082)\end{array}$ & $\begin{array}{l}0.067^{* * *} \\
(0.0114)\end{array}$ & $\begin{array}{l}0.039 * * * \\
(0.0104)\end{array}$ & $\begin{array}{l}0.039^{* * *} \\
(0.0104)\end{array}$ & $\begin{array}{l}0.050 * * * \\
(0.0084)\end{array}$ \\
\hline May & $\begin{array}{l}0.083^{* * *} \\
(0.0086)\end{array}$ & $\begin{array}{l}0.079^{* * *} \\
(0.0118)\end{array}$ & $\begin{array}{l}0.038^{* * *} \\
(0.0107)\end{array}$ & $\begin{array}{l}0.038^{* * *} \\
(0.0107)\end{array}$ & $\begin{array}{l}0.042^{* * *} \\
(0.0090)\end{array}$ \\
\hline June & $\begin{array}{l}0.128^{* * *} \\
(0.0080)\end{array}$ & $\begin{array}{l}0.117^{* * *} \\
(0.0106)\end{array}$ & $\begin{array}{l}0.045^{* * *} \\
(0.0098)\end{array}$ & $\begin{array}{l}0.046^{* * *} \\
(0.0098)\end{array}$ & $\begin{array}{l}0.042^{* * *} \\
(0.0085)\end{array}$ \\
\hline July & $\begin{array}{l}0.107^{* * *} \\
(0.0081)\end{array}$ & $\begin{array}{l}0.104^{* * *} \\
(0.0108)\end{array}$ & $\begin{array}{l}0.052^{* * *} \\
(0.0099)\end{array}$ & $\begin{array}{l}0.052^{* * *} \\
(0.0099)\end{array}$ & $\begin{array}{l}0.044^{* * *} \\
(0.0085)\end{array}$ \\
\hline August & $\begin{array}{l}0.083^{* * *} \\
(0.0104)\end{array}$ & $\begin{array}{l}0.094^{* * *} \\
(0.0145)\end{array}$ & $\begin{array}{l}0.052^{* * *} \\
(0.0133)\end{array}$ & $\begin{array}{l}0.053^{* * *} \\
(0.0133)\end{array}$ & $\begin{array}{l}0.041^{* * *} \\
(0.0105)\end{array}$ \\
\hline September & $\begin{array}{l}0.065^{* * *} \\
(0.0085)\end{array}$ & $\begin{array}{l}0.061^{* * *} \\
(0.0130)\end{array}$ & $\begin{array}{l}0.020 \\
(0.0117)\end{array}$ & $\begin{array}{l}0.020 \\
(0.0117)\end{array}$ & $\begin{array}{l}0.022^{*} \\
(0.0094)\end{array}$ \\
\hline October & $\begin{array}{l}0.063^{* * *} \\
(0.0052)\end{array}$ & $\begin{array}{l}0.042^{* * *} \\
(0.0080)\end{array}$ & $\begin{array}{l}0.004 \\
(0.0073)\end{array}$ & $\begin{array}{l}0.004 \\
(0.0073)\end{array}$ & $\begin{array}{l}0.004 \\
(0.0058)\end{array}$ \\
\hline November & $\begin{array}{l}0.050^{* * *} \\
(0.0059)\end{array}$ & $\begin{array}{l}0.040^{* * *} \\
(0.0093)\end{array}$ & $\begin{array}{l}0.010 \\
(0.0084)\end{array}$ & $\begin{array}{l}0.010 \\
(0.0084)\end{array}$ & $\begin{array}{l}0.013^{*} \\
(0.0064)\end{array}$ \\
\hline December & $\begin{array}{l}0.038^{* * *} \\
(0.0066)\end{array}$ & $\begin{array}{l}0.029 * * \\
(0.0108)\end{array}$ & $\begin{array}{l}0.005 \\
(0.0097)\end{array}$ & $\begin{array}{l}0.004 \\
(0.0097)\end{array}$ & $\begin{array}{l}-0.009 \\
(0.0077)\end{array}$ \\
\hline Costs per kWh & $\begin{array}{l}-0.000^{*} \\
(0.0001)\end{array}$ & $\begin{array}{l}-0.003^{* * *} \\
(0.0007)\end{array}$ & $\begin{array}{c}-0.003^{* * *} \\
(0.0007)\end{array}$ & $\begin{array}{c}-0.003^{* * *} \\
(0.0007)\end{array}$ & $\begin{array}{l}-0.003^{* * *} \\
(0.0007)\end{array}$ \\
\hline Year of Construction & & & & $\begin{array}{c}-0.0001^{*} \\
(0.0001)\end{array}$ & \\
\hline Minimum EPC score & & & & & $\begin{array}{l}0.005^{* * *} \\
(0.0002)\end{array}$ \\
\hline HDD 12 month sum & $\mathrm{Y}$ & $\mathrm{Y}$ & $\mathrm{Y}$ & $\mathrm{Y}$ & $\mathrm{Y}$ \\
\hline HDD 3 month sum & $\mathrm{Y}$ & $\mathrm{Y}$ & $\mathrm{Y}$ & $\mathrm{Y}$ & $\mathrm{Y}$ \\
\hline Year FE & Yes & Yes & Yes & Yes & Yes \\
\hline \# of Apts X PLZ FE & Yes & Yes & Yes & Yes & Yes \\
\hline Building Code FE & & & Yes & Yes & Yes \\
\hline Sample & All & $\mathrm{EPC}$ & $\mathrm{EPC}$ & $\mathrm{EPC}$ & EPC \\
\hline$N$ & $1,605,802$ & 752,629 & 752,629 & 752,629 & 752,629 \\
\hline Adj $R^{2}$ & 0.314 & 0.434 & 0.495 & 0.495 & 0.591 \\
\hline
\end{tabular}

Note: The control or omitted group consists of buildings with calendar year billing. Robust standard errors clustered at the building level. ${ }^{*} p<0.05,{ }^{* *} p<0.01,{ }^{* * *} p<0.001$. 
Table 23: District Heating Buildings with Energy Performance Certificates Calendar Year Versus Other Billing Cycles

\begin{tabular}{|c|c|c|c|c|c|}
\hline \multirow[t]{2}{*}{ Bill Start } & \multicolumn{4}{|c|}{ Dependent variable: $\ln \left(\mathrm{kWh} / \mathrm{m}^{2}\right)$} & \multirow[b]{2}{*}{$(5)$} \\
\hline & (1) & $(2)$ & $(3)$ & $(4)$ & \\
\hline May to July & $\begin{array}{l}0.080 * * * \\
(0.0179)\end{array}$ & $\begin{array}{l}0.090 * * * \\
(0.0261)\end{array}$ & $\begin{array}{l}0.074^{* *} \\
(0.0257)\end{array}$ & $\begin{array}{l}0.074^{* *} \\
(0.0257)\end{array}$ & $\begin{array}{l}0.074^{* *} \\
(0.0249)\end{array}$ \\
\hline Costs per kWh & $\begin{array}{c}-0.000^{* *} \\
(0.0001)\end{array}$ & $\begin{array}{c}-0.002^{* *} \\
(0.0006)\end{array}$ & $\begin{array}{c}-0.002^{* *} \\
(0.0006)\end{array}$ & $\begin{array}{c}-0.002^{* *} \\
(0.0006)\end{array}$ & $\begin{array}{c}-0.002^{* *} \\
(0.0007)\end{array}$ \\
\hline Year of Construction & & & & $\begin{array}{l}0.000 \\
(0.0002)\end{array}$ & \\
\hline Minimum EPC score & & & & & $\begin{array}{l}0.006^{* * *} \\
(0.0002)\end{array}$ \\
\hline HDD 12 month sum & $\mathrm{Y}$ & $\mathrm{Y}$ & $\mathrm{Y}$ & $\mathrm{Y}$ & $\mathrm{Y}$ \\
\hline Year FE & Yes & Yes & Yes & Yes & Yes \\
\hline \# of Apts X PLZ FE & Yes & Yes & Yes & Yes & Yes \\
\hline Building Code FE & & & Yes & Yes & Yes \\
\hline Sample & All & $\mathrm{EPC}$ & $\mathrm{EPC}$ & $\mathrm{EPC}$ & EPC \\
\hline$N$ & 256,343 & 146,393 & 146,393 & 146,393 & 146,383 \\
\hline $\operatorname{Adj} R^{2}$ & 0.572 & 0.616 & 0.619 & 0.619 & 0.627 \\
\hline
\end{tabular}

Note: The control or omitted group consists of buildings with calendar year billing. Robust standard errors clustered at the building level. ${ }^{*} p<0.05,{ }^{* *} p<0.01,{ }^{* * *} p<0.001$. 
Table 24: Buildings with WSVO 1995 Standards

Calendar Year Versus Non-Heating Months

\begin{tabular}{|c|c|c|c|}
\hline \multirow[t]{2}{*}{ Bill Start } & \multicolumn{3}{|c|}{$\ln \left(\mathrm{kWh} / \mathrm{m}^{2}\right)$} \\
\hline & (1) & $(2)$ & $(3)$ \\
\hline May to July & $\begin{array}{l}0.0877^{* *} \\
(0.0334)\end{array}$ & $\begin{array}{l}0.0844^{* *} \\
(0.0312)\end{array}$ & $\begin{array}{l}0.0920^{* *} \\
(0.0306)\end{array}$ \\
\hline Costs per kWh & $\begin{array}{l}-0.0740^{* * * *} \\
(0.0022)\end{array}$ & $\begin{array}{l}-0.0745^{* * *} \\
(0.0019)\end{array}$ & $\begin{array}{l}-0.0827^{* * *} \\
(0.0224)\end{array}$ \\
\hline HDD 12 month sum & $\mathrm{Y}$ & $\mathrm{Y}$ & $\mathrm{Y}$ \\
\hline HDD 3 month sum & $\mathrm{Y}$ & $\mathrm{Y}$ & $\mathrm{Y}$ \\
\hline Year of Construction & & $\mathrm{Y}$ & $\mathrm{Y}$ \\
\hline Heat System Year & & $\mathrm{Y}$ & $\mathrm{Y}$ \\
\hline Year FE & Yes & Yes & Yes \\
\hline$\#$ of Apts X PLZ FE & Yes & Yes & Yes \\
\hline Building Code FE & & Yes & Yes \\
\hline Fuel Type FE & & & Yes \\
\hline Fuel Type & -Natur & 1 Gas- & All \\
\hline$N$ & 101,540 & 101,483 & 133,445 \\
\hline $\operatorname{Adj} R^{2}$ & 0.658 & 0.677 & 0.680 \\
\hline
\end{tabular}

Note: The control or omitted group consists of buildings with calendar year billing.

"All" fuel types refers to mineral oil, natural gas $\mathrm{H}$, and district heating.

Robust standard errors clustered at the building level. ${ }^{*} p<0.05,{ }^{* *} p<0.01,{ }^{* * *} p<0.001$. 


\section{A Appendix}

Figure A1: Evolution of Heating Fuel Prices in Germany

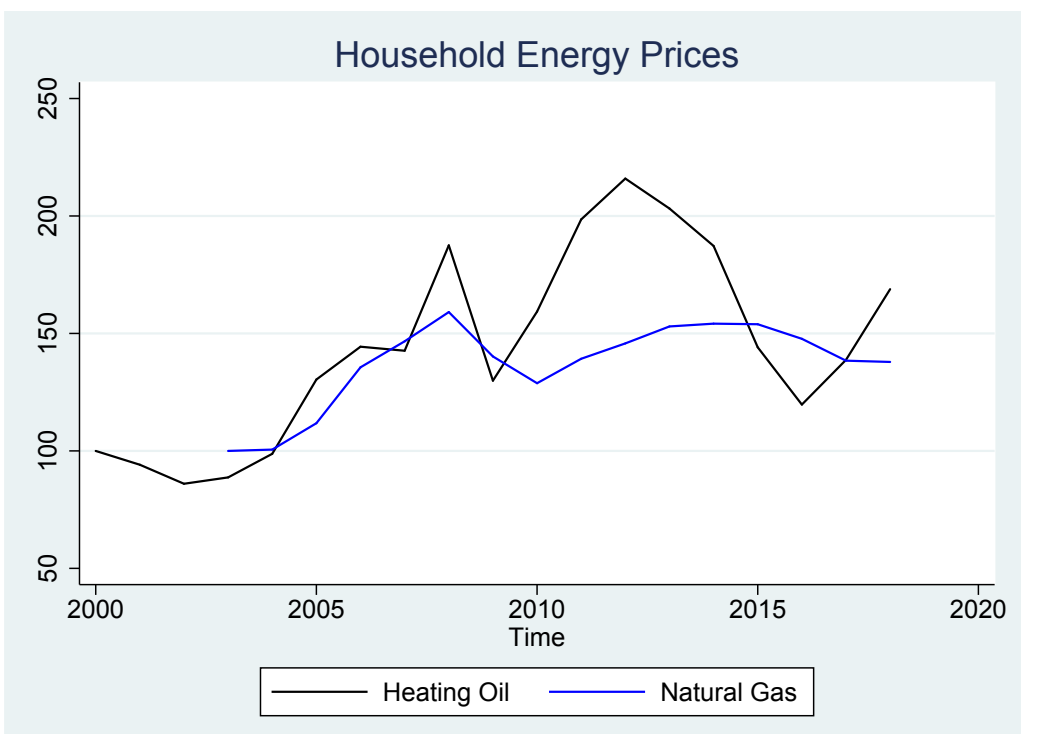

Note: The heating oil series presents annual consumer prices for light heating oil (for consumption of 5000 liters) in Euro cents per liter and natural gas series presents annual averages of biannual household prices in Euros per gigajoule. Due to data limitations, the natural gas price index is calculated using a combination of two different time series: (1) 2003 to 2007 price data applies to consumption class between 20 and 200 GJ and (2) 2008 to 2018 price data applies to consumption of 83.70 GJ. Both price series include all taxes and fees. For plotting, the raw data were indexed: heating oil $(2000=100)$ and natural gas $(2003=100)$. Sources: Mineralöl Wirtschaftsverband e.V. for leichtes Heizöl and Eurostat Datenbank for Preise Gas für Haushaltskunde.

Figure A2: Distribution of Heat Demand

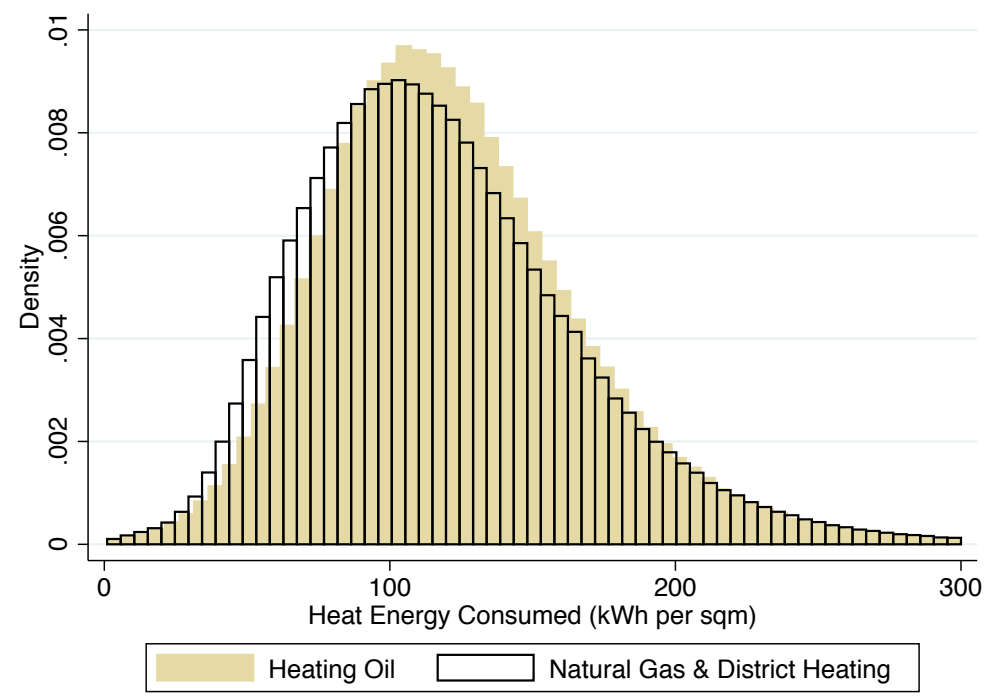

Note: The histogram presents the distribution of annual heat energy consumed, limited to less than $300 \mathrm{kWh}$ per square meter. 
Figure A3: Rate of Overconsumption

Plot A

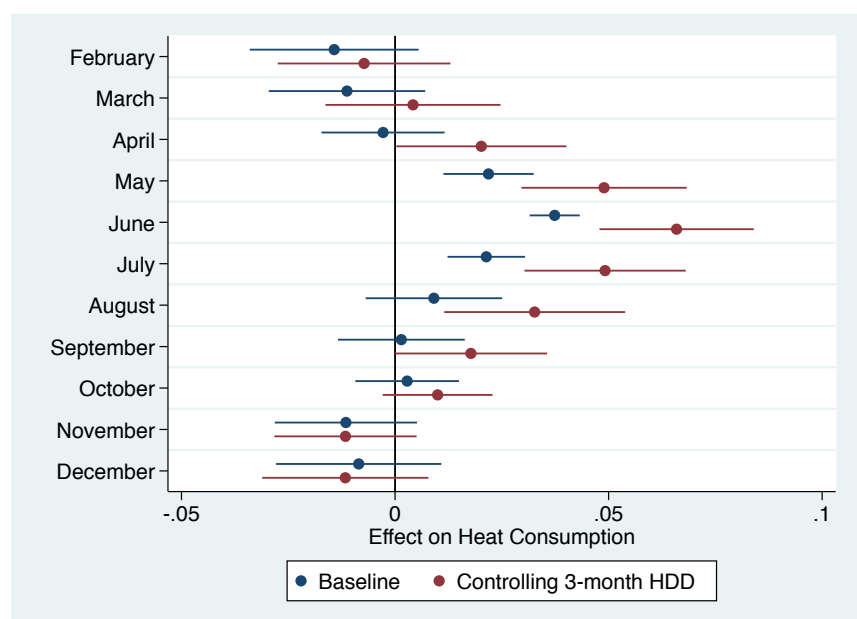

Plot B

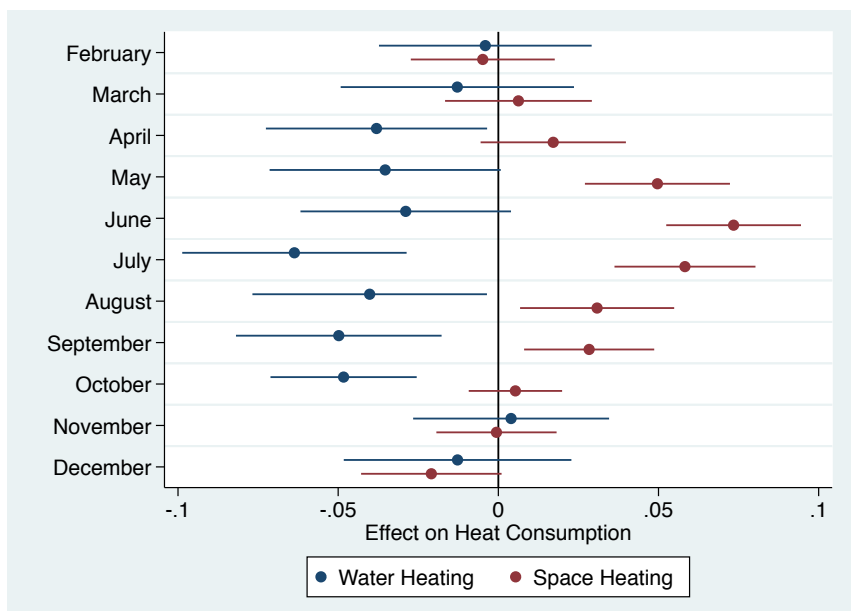

Note on Plot A: Graph shows that bills that are settled during non-usage months (May to September) are subject to overconsumption, relative to the calendar year billing cycle. 95\% confidence intervals provided. Estimates for bills ending in May, June, and July are highly precise. Controlling for differences in the annual sum of heating degree days in the first 3 months post-billing strengthens the pattern.

Note on Plot B: Heating bills cover costs incurred for water heating, in addition to space heating. Residential demand for fuel energy to heat water is less seasonal than that for space heating. Graph shows that HHs that are indeed paying attention to bills during the summer months adjust (disproportionately) the amount of energy they consume for water heating. 95\% confidence intervals provided.

Figure A4: Trimmed Dependent Variable

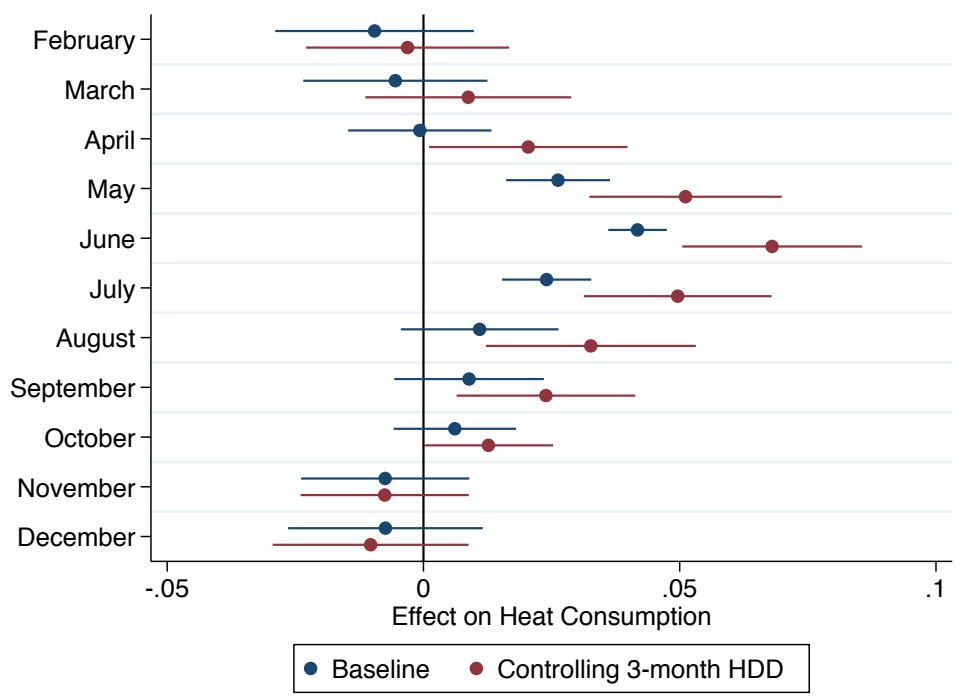

Note: The graph plots the treatment effect coefficients in Plot A of Figure A3, after discarding heating bills that report heat demand greater than or equal to $300 \mathrm{kWh}$ per square meter (approximately $0.7 \%$ of the observations) . 